\title{
HISTORIOGRAFÍA DE LA DAMA DE ELCHE. SUS PROTOTIPOS DE FUERA DE HISPANIA ${ }^{1}$
}

\author{
JOSÉ MARÍA BLÁZQUEZ \\ Real Academia de la Historia
}

\begin{abstract}
En este trabajo hemos querido recoger, siguiendo en lo posible el orden cronológico, las principales opiniones que los investigadores han expuesto sobre esta excepcional pieza del arte ibérico. Incluimos testimonios antiguos y poco conocidos, asi como opiniones y documentos inéditos amablemente cedidos por sus autores. A todo ello añadimos nuestras consideraciones personales, producto de muchos años de estudio de la cultura ibérica.
\end{abstract}

In this paper we have tried to collect in a cronological order the most relevant opinions on this exceptional piece of Iberian art. We include rare ancient evidence as well as opinions and unpublished ocuments kindly transferred by the owners. We also add our own considerations, established after years of studies on Iberian culture.

Antes de comenzar el trabajo propiamente dicho, queremos reproducir a modo de introducción, la descripción y el estudio que de esta excepcional pieza del arte ibérico, realizó A. Blanco, mi maestro, un excelente conocedor del arte ibérico y clásico (Blanco, 1981, 97-50). Con ello pretendo honrar su memoria. Dice asi:

"El busto (Fig. 1 y 2) labrado en la caliza porosa típica de la región, mide 56 centímetros de alto, y se muestra en actitud rigurosamente frontal, cubierto de grandes y lujosos aderezos. Al carácter macizo y poco esbelto de la figura, con su cuello ancho y sus hombros muy levantados, se suma el efecto de rigidez de su complejo tocado, que por detrás parece atenazar la cabeza e impedirle girar sobre el cuello. En contraste con la representación realista de sus vestidos y joyas, la cabeza es una construcción puramente ideal, de formas regulares, amplias y sobriamente modeladas. Bajo la espaciosa frente y los finos arcos de las cejas, los ojos oblicuos, de finos párpados, parecen dirigir la mirada a un objeto próximo, que se encuentra en un plano algo más bajo que el de la cabeza (el iris y la pupila estarian hechos en piezas independientes, que se han perdido). La nariz es recta, regular; las mejillas, anchas y de pómulos altos; la barbilla, redonda, fuerte y un poco saliente; la boca, de labios finos, apretados, de igual longitud y perfectamente delineados en sus contornos.

Los adornos de la cabeza consisten en una gran peineta, cubierta por un velo a través del cual se ven en el dorso una serie de líneas dispuestas como los surcos de una concha, que son sin duda el trasunto de la ornamentación de la peineta. Por encima del velo, rodea la cabeza una funda tirante, que deja exenta la zona correspondiente a la concha de la peineta; en su parte anterior, sobre la frente de la Dama, dicha funda está adornada por tres líneas de botones semiesféricos (perdidos casi todos los de la hilera inferior). A los lados de la cara, esta pieza sujeta dos grandes discos, unidos entre si por un tirante que cruza la cabeza. Los discos llevan por su cara interior unos cierres con volutas dobles, de los que caen sobre el cuello colgantes funiculares, con remates en forma de perilla.

El busto está revestido de una túnica interior, cerrada sobre el cuello por una diminuta fíbula anular. Por encima de ésta, otro vestido, de tela más gruesa, cruza el pecho en diagonal,

\footnotetext{
1 Agradecemos a los profesores J.M. Uroz, J.M. Abascal y L. Abad de la Universidad de Alicante; M. Bendala y A. Domínguez Monedero de la Universidad Autónoma de Madrid; J. Alvar de la Universidad Carlos III; R. Olmos, G. López Monteagudo y T. Tortosa del C.S.I.C., y al Dr. J. Cabrero la ayuda prestada por este estudio.
} 


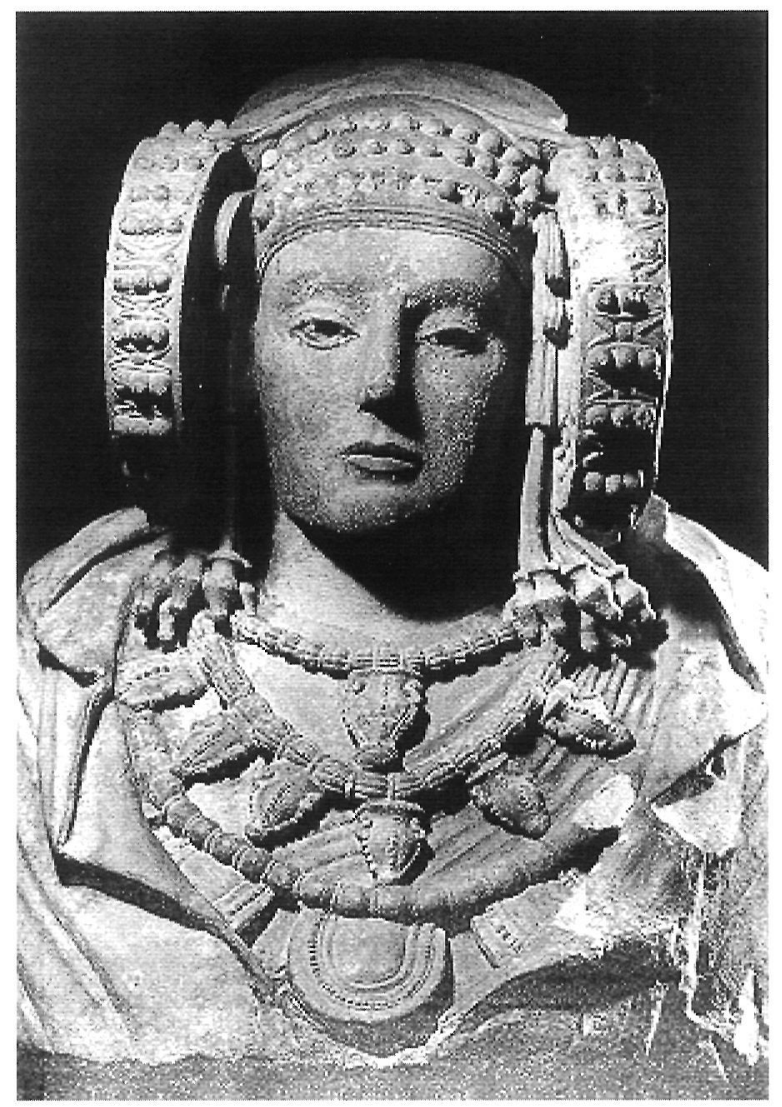

Figura 1: Dama de Elche. Foto IAA de Madrid

y sobre todo ello el manto viene desde los hombros a cerrarse en la base y centro del busto dejando asomar los tres collares que cruzan el pecho. Los dos primeros collares se componen de hilos atados en haces y llevan amuletos en forma de ánfora; el tercero está formado por cuentas, y sus amuletos tienen forma de lengüeta.

El busto ofrece por detrás una cavidad, cuyo destino se ignora. Pudiera estar dispuesta para guardar cenizas, como lo estaba la cavidad del trono de la Dama de Baza.

La indumentaria de la Dama es típicamente ibérica y similar a la de otras muchas figuras femeninas, grandes y pequeñas, esculpidas en piedra o modeladas en barro, fundidas en bronce e incluso pintadas en los vasos cerámicos levantinos. Pero en ningún caso, ni siquiera en el de la Dama de Baza, fue el artista tan cuidadoso como aquí en la fiel representación de los detalles. Si bien no conocemos aún ejemplos reales de los elementos que componen el tocado, pueden estudiarse éstos en la escultura. Parece que todas las piezas no cubiertas por el manto eran partes de un todo: la funda que ciñe la cabeza por encima del velo, tal vez de cuero o incluso posiblemente de metal, se ensancha por arriba hasta cerca del canto de la peineta y sujeta los grandes cilindros o discos laterales. El griego Artemidoro, que estuvo en España hacia el año 100 a. C., describe entre los tocados al uso uno que pudiera ser éste: en otros sitios (las mujeres ibéricas) se cubren con el tympánion (=pandereta), que rodea la nuca y ciñe la cabeza hasta el lóbulo de las orejas, haciéndose más alto y ancho al dirigirse hacia atrás (Str. III.4.17). La descripción se ajusta más -nótese el detalle de "hasta el lóbulo de las orejas"- al tocado de la Dama de Baza, pero el nombre de "pandereta" convendría a los discos laterales de esta otra dama. Los detalles de la ornamentación de estos discos nos son conocidos por joyas ibéricas de oro y plata. El Museo Arqueológico Nacional posee parte de un disco de filigrana de plata que pudo haber pertenecido a un rodete como éstos, quizá sobre armadura de cuero o de madera. En los cantos de los discos de la Dama alternan flores rectangulares, de cuatro hojas, con semiesferas que llevan un glóbulo en su centro. Idénticas flores se encuentran en la diadema de Jávea e idénticas semiesferas en una de las caras de los suntuosos pendientes de Santiago de la Espada (Jaén). La moda

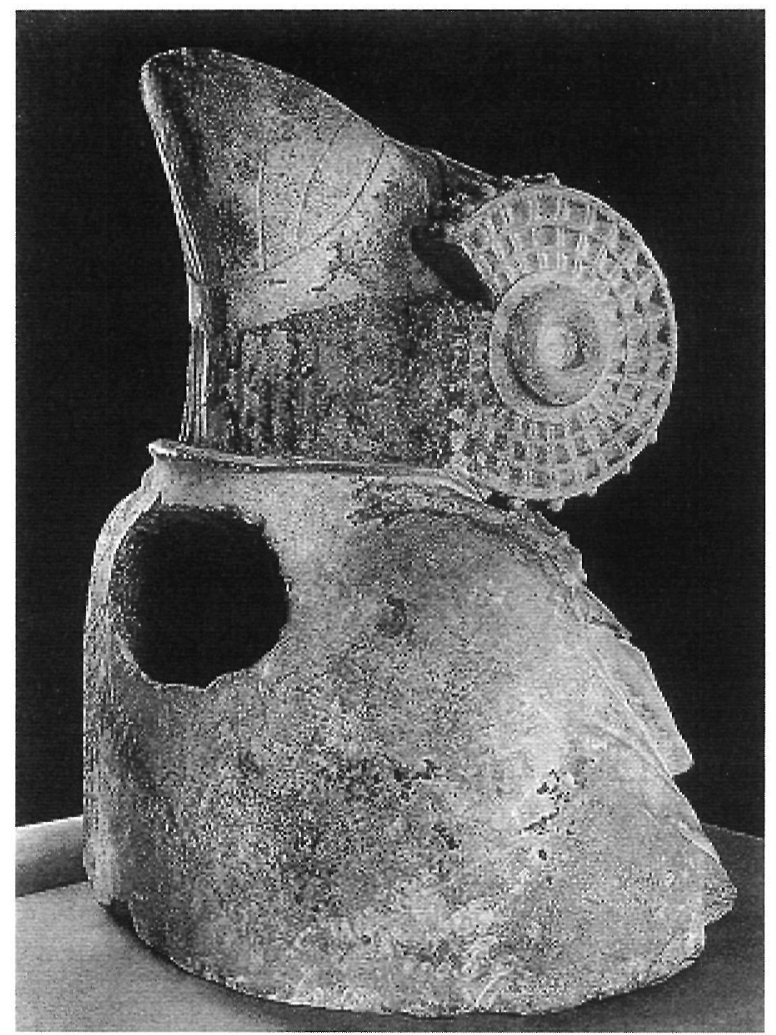

Figura 2: Parte posterior del busto de la Dama de Elche. Foto IAA de Madrid. 
ibérica levantina tiene sus más próximas equivalencias no en el mundo de las colonias fenicias, como sería de esperar, sino en la indumentaria itálica y en particular etrusca de fines del siglo VI, donde se encuentran tocados tan complejos y joyas tan voluminosas. En la Península, según la escultura ibérica tardía y el testimonio de autores como Artemidoro, esas modas parecen haberse ritualizado y permanecido hasta fechas mucho más recientes.

También los adornos del busto cuentan con paralelos en las representaciones de damas ibéricas y en joyas reales como los collares de La Aliseda (amuletos en forma de lengüeta, de origen fenicio), o una anforilla de oro con tapadera de la Colección Calzadilla, La fíbula anular de tipo hispánico, que aparece en esta estatua en el borde de la túnica, se encuentra ya en los yacimientos ibéricos desde comienzos del siglo $\mathrm{V}$.

La cabeza de kore de Alicante (?) y la cabecita con trenzas de la propia Elche indican que la escultura iberofenicia se implanta en esta comarca a finales del siglo VI a.C. La Dama de Elche representa una fase más adelantada, clásica ya, respaldada en su tipo concreto por otro modelo jónico -y luego suritálico- el de la estatua sedente como la vemos en Verdolay (Murcia). El tipo hizo fortuna. Con variantes de indumentaria y tamaño lo encontramos en el Cerro de los Santos y en Baza, pero también en Elche, aquí en un fragmento de tamaño natural que insinúa la sospecha de que si la Dama no fue originariamente un busto haya resultado de la fragmentación de una figura similar. En este fragmento ilicitano la mujer lleva en la mano izquierda unas flores de adormidera como posible indicación de su carácter funerario.

Ninguna otra de las esculturas halladas en Elche alcanza por ahora la perfección de la Dama. Ello hace pensar que acaso ésta no fuese una dama como las demás, sino una diosa ataviada de todos los adornos de que la devoción ibérica era capaz de colmarla. El hecho mismo de que haya llegado a nosotros virtualmente intacta, gracias a las losas depiedra y demás precauciones que ya en la Antigüedad se habian tomado para protegerla y evitar su destrucción, nos hacen creer que para los ilicitanos no era una estatua ordinaria. Es de tener presente que la única estatua parecida y de la misma región que sabemos positivamente quién era, porque una inscripción latina nos lo dice, es la de una diosa sedente de época romana republicana hallada en
Mazarrón (Murcia). El nombre que la inscripción proporciona es el de Terra mater.

Comoquiera que sea, el estilo moldeado en lo griego de la kore de Alicante (?) ha alcanzado aquí la perfección de lo clásico. La expresión reconcentrada, de profundo ensimismamiento, representa de modo insuperable el contacto de lo humano con lo divino, que se produce merced a los misterios o en la práctica de los más altos sacramentos. Este pudiera ser el carácter hispánico de la figura, lo que no debe a ningún modelo ni influencia, lo que la hace única en la estimación de muchos, sobre todo extranjeros, que ven en ella algo que responde a su idea del carácter español.

La conclusión cronológica a que por estas vías se llega es a la de situar la Dama en la periferia del arte griego de la primera mitad del siglo $\mathrm{V}$. El único grave inconveniente con que esta datación tropieza es el de que el estrato que en Elche proporcionan las esculturas es fechado por su mejor conocedor y propietario del terreno, Alejandro Ramos Folqués, un siglo más tarde".

\section{PAUL JACOBSTAHL}

En 1932, Paul Jacobstal (Jacobstahl, 1932, 67-73), catedrático entonces de Arqueología de la Universidad de Marburgo, y uno de los mejores conocedores de la arqueología clásica de su época, publicó un trabajo fundamental sobre el peinado del busto de la Dama de Elche, que ha pasado prácticamente desapercibido para la historiografía posterior. Su tesis es la siguiente:

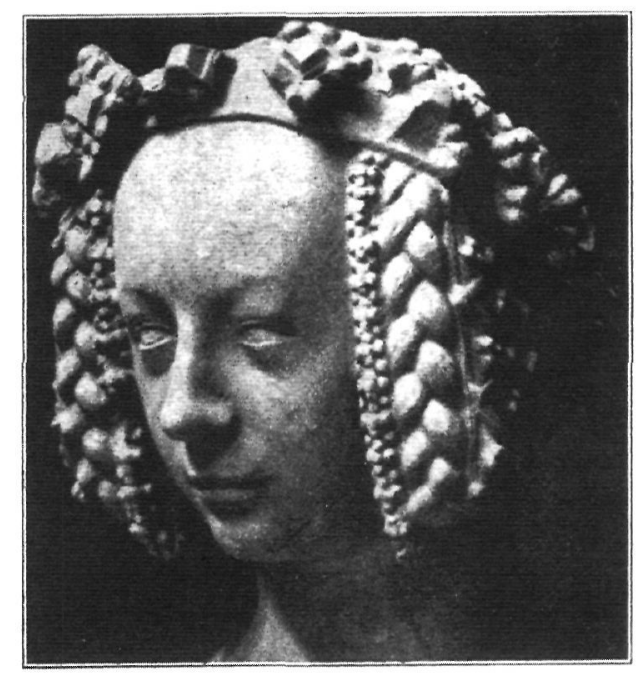

Figura 3: Dama de Poitiers. Según P. Jacobsthal. 

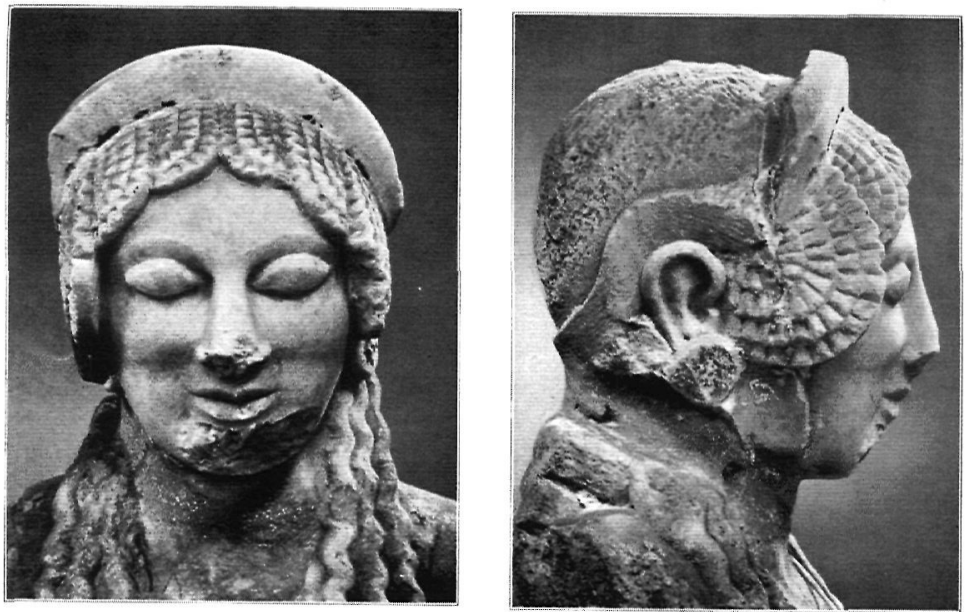

Figura 4: Kore del Museo Nacional de Atenas. Según P. Jacobsthal.

Los muchos adornos de la Dama de Elche nos llevan a esculturas del Cerro de los Santos y a varias terracotas (Almagro Gorbea, 1980, 128, 129, láms. LXVIII-LXIX) y bronces ibéricos. Desde la Tettix de Hauser se sabe que en cualquier momento el peinado natural se convierte en oro. Los caracoles del pelo, ya sea del propio pelo o del de otras personas, se transforman en oro. En la Península Ibérica no existen pruebas de este peinado en el siglo $\mathrm{V}$ a.C., pero los griegos ya conocian esta moda. Para una etapa posterior a la arcaica, el mejor ejemplo de este peinado es la Cabeza de Poitiers, antigua colección de J. de Bouloge (Fig. 3).

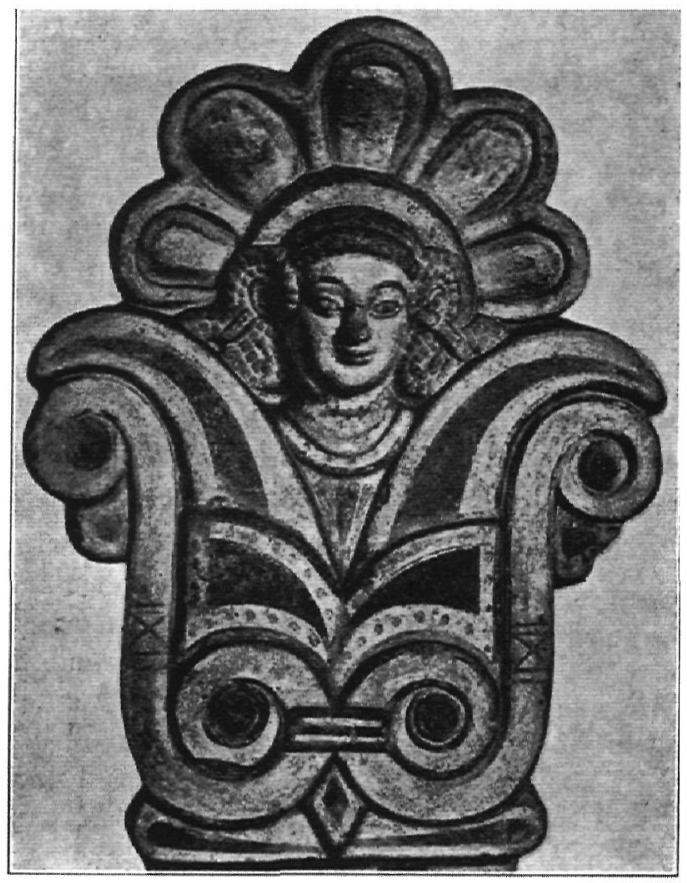

Figura 5: Kore de un tejado de Capua. Según P. Jacobsthal.
En numerosas korai, el tratamiento del pelo de la frente y de las sienes es el siguiente. Desde la raya central parten dos mechones de pelo a ambos lados de la cabeza y desde el pelo que cae sobre la frente y cubre los dos mechones, delante de las sienes, se peina el cabello en forma de arco, hacia abajo, y se vuelve sobre las orejas y cae sobre la nuca. Los ejemplos son las korai conservadas en el Museo de la Acrópolis de Atenas, n. 671; n. 689; n. 666 (Fig. 4); n. 24, procedente de Eleusis; n. 688 ; n. 60 , también de Eleusis; y la de Egina en la Glyptoteka de Munich; también la kore de Villa Borghese y el retrato Arndt.

Atenea, en la época arcaica, llevaba este peinado, como muestran la chapa de bronce del Museo Nacional de Atenas, n. 6448.; la

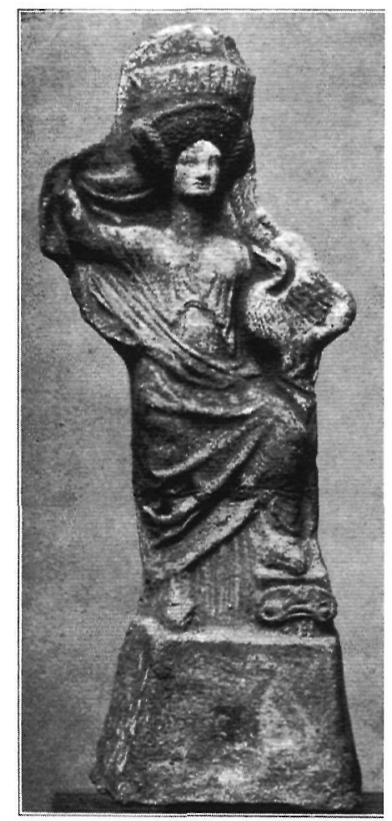

Figura 6: Némesis de Berlin. Según P. Jacobsthal. 


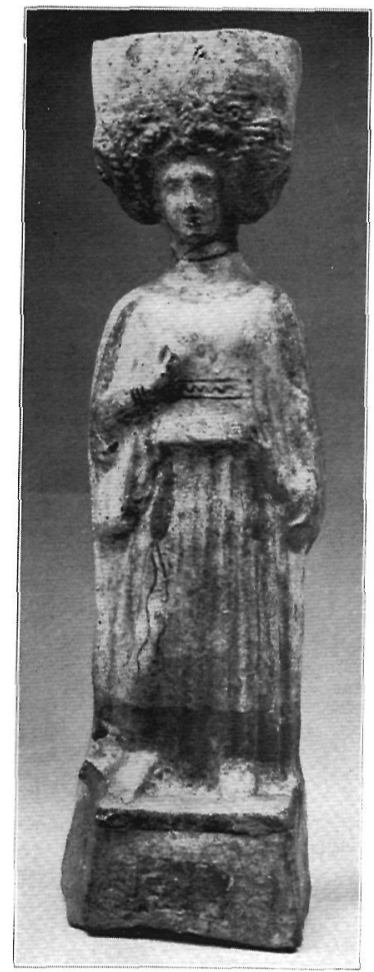

Figura 7: Tanagra. Museo Nacional de Atenas. Según P. Jacobsthal.

estatua de Melexo del Museo Nacional de Atenas, n. 6447; la Atenea de Villa Albani; la antefija etrusca con cabeza, de Seggiano, en Florencia. En pintura vascular no existe ningún ejemplo seguro de este peinado. También se conocen figuras fechadas a comienzos de la época imperial con este peinado: la kore de la Villa Albani; la cabeza de la colección Matsch; la cabeza del British Museum; las cabezas de Bruselas y de la Gliptoteca Ny Carlsberg; la cabeza de Atenea de New York, etc.

Una forma de variante, un tanto artificial, de este peinado, lleva la cabeza de una muchacha del Tejado de Capua fechada a comienzos del s. V a.C. (Fig. 5). Acertadamente A. Koch propone que el peinado de esta cabeza de Capua es el prototipo real de esta forma de peinado. La diferencia consiste en que los mechones de pelo de las sienes no caen abiertos detrás de los oídos, verticalmente, sino que están sujetos hacia arriba por una pinza de metal y unidos con el pelo detrás de los oídos.

Todos estos ejemplos fechados en la época arcaica, son los prototipos de las ruedas de la Dama de Elche.

Estas ruedas de pelo a ambos lados de las orejas se encuentran en muchas terracotas de final del s. V a.C., halladas en Beocia y en

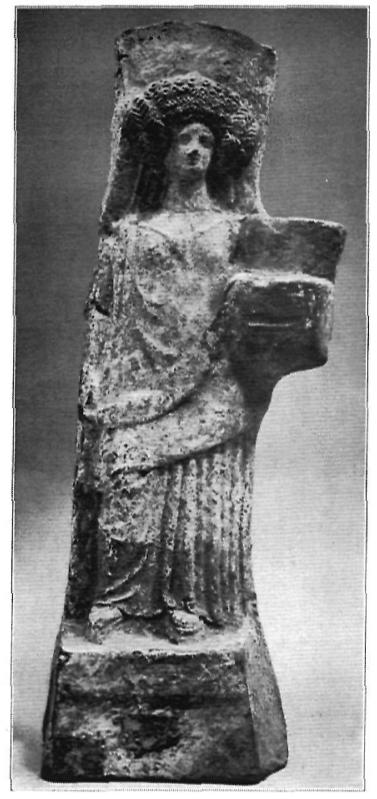

Figura 8: Terracota. Museo Nacional de Atenas. Según P. Jacobsthal.

Locris. Todas las muchachas que llevan este peinado participaban activamente en el culto, pues llevaban tenias (cintas o bandas) sueltas o anudadas, cajitas redondas o cuadradas, cuencos, frutos y ramas. Una de estas jovencitas sostiene un cerdo para sacrificarlo. La Némesis de Berlín lleva también el mismo peinado (Fig. 6), al igual que la tanagra del Museo Nacional de Atenas (Fig. 7), la muchacha de Locris y otra de la misma procedencia, también conservadas en el Museo Nacional de Atenas (Fig. 8). Una terracota del mismo museo (Fig. 9) y otros ejemplos tienen poco pelo sobre
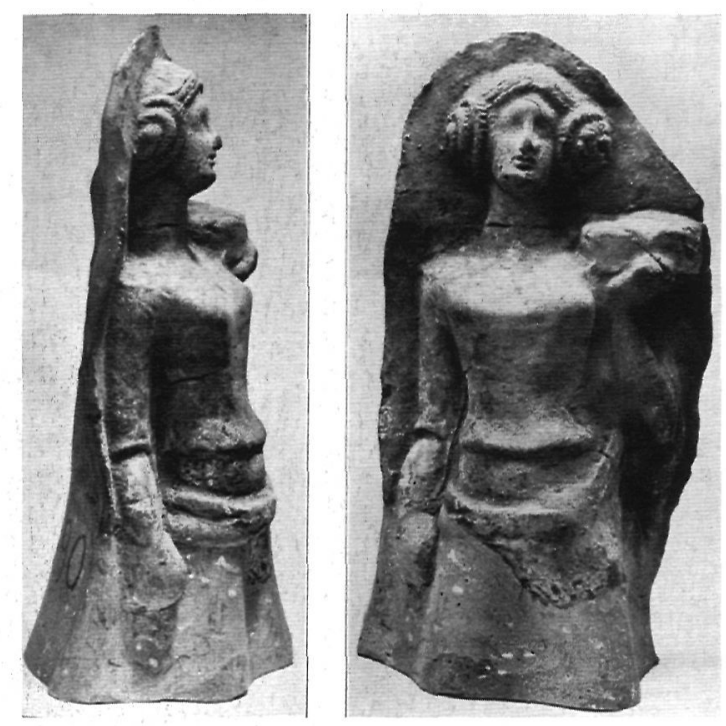

Figura 9: Terracota. Museo Nacional de Atenas. Según P. Jacobsthal. 
la frente, lo que parece indicar que el pelo es propio y no postizo. En otros casos, el peinado es tan aparatoso que debe ser hecho a propósito para el culto. En resumen, todas estas terracotas, fechadas a finales del s. $\mathrm{V}$, presentan un peinado antiguo artificial e ingenioso, con rodetes sobre las orejas, que es el prototipo para los rodetes de oro de la Dama de Elche.

\section{ERNST LANGLOTZ}

En 1951, el catedrático de arqueología de la Universidad de Bonn y maestro de A. Blanco, Ernst Langlotz, en su publicación en el homenaje a Robinson, el excavador de Olinto, pone en relación el estilo de la Dama de Elche con el de la Hera del santuario de Selinunte en Sicilia (Langlotz, 1951, 646; 1983, 83-90, láms. 100-113).

Sobre el arte de este santuario siciliano, tan importante para conocer el estilo de la Dama de Elche, la opinión del profesor germano es la siguiente:

Las metopas del templo de Hera en Selinunte son las más importantes de todo el oeste de Grecia. Son obra de un conjunto de artesanos. De las 12 originales sólo se conservan 5 bastante bien. Las cabezas conservadas son de cuatro maestros diferentes y están en cuatro metopas diferentes. El material con el que están hechas es de arenisca, pero tienen de mármol los pies, las manos y las cabezas. La composición de Atenea y Enkelados es menos fina y su forma ofrece rasgos arcaicos. Las cabezas más perfectas son las de Zeus y de Hera, y la metopa de Acteón (Fig. 10). La caída de las amazonas, estilisticamente, es algo torpe. Sólo se puede decidir subjetivamente si las cabezas de las mujeres trabajadas en mármol pertenecen al mismo taller que las cabezas en arenisca, de los varones. E. Langlotz opina que son de artesanos diferentes. Las mejores cabezas de mármol no acusan huellas de arcaísmo, pero en los cuerpos de Hera (Fig. 11-12) y de Ártemis (Fig. 13), es posible reconocerlo aún. Se ha discutido la fecha de las metopas. Debían haberse acabado antes de terminar la cella. Los motivos de las imágenes corresponden a la fase temprana del estilo severo. El templo se ha fechado en 470 a.C., y según los ropajes, las figuras deberian corresponder al 460 a.C.
Las cabezas de Hera y alguna otra (Fig. 14-16) se datan en 460-450 a.C. El trabajo duró 20 años. Las metopas del lado sur se terminaron en 6 años. Igualmente se observan en ellas diferencias estilisticas (Fig. 17). Seguramente, las metopas de Hera en Selinunte se podian fechar en 450 a.C. En el s. VI a.C., trabajaba ya un taller de artistas, en arenisca, en Selinunte. Se discute si los artistas de las cabezas de mármol eran artesanos de Selinunte o sicilianos, artesanos de la Magna Grecia o artesanos ambulantes de Grecia. Aunque se observa una gran diferencia en las calidades (Fig. 18), el tipo de cabeza es similar en todas, y en algunos rasgos se las puede relacionar con las obras de Pitágoras, aunque no todas están influidas por el arte de este artista, al que según algunos autores podrían corresponder los Bronces de Riace (Moreno, 1991). Sólo una cabeza de frente, la cabeza de una amazona y la cabeza de Heracles siguen otro modelo ideal de cabeza menos fina. Estas cabezas están próximas a la cabeza de la Escuela de Como. Es importante la discusión sobre la procedencia del mármol y de los artistas. El mármol no es pentélico. Faltan argumentos para decidir si la cabeza de estilo más griego procede de un artista llegado de Grecia o no.

Paralelamente a este grupo de cabezas, probablemente de personas, un segundo grupo pertenece al arte provincial de la Magna Grecia, según E. Langlotz. Entre ellas tenemos la del Museo de las Termas, en Roma, una del Museo de Como, otra de Hannover, un relieve de Boston y otra cabeza femenina de Siracusa. También dos cabezas del Louvre, una de ellas la llamada cabeza de Cumas, la Nike de Locris, en Reggio, una cabeza femenina de Tarento (Fig. 19), la cabeza y los pies de una imagen de culto de Giro, en Reggio (Fig. 20) y la voluta de una esquina, parecida a las cabezas de Selinunte, en Toulouse. Además, un relieve, próximo a las cabezas tardías arcaicas de Italia del sur, una figura de Elche, en Madrid, comparable a la Hera de Selinunte; una cabeza de diosa de Tarento de Kansas City, otra cabeza más (Fig. 21) y el relieve de una tumba también en Tarento. Añade un relieve de jinete del Museo de las Termas de Roma, un relieve con ménades danzando en la Ny Carlsberg de Copenhague y el relieve de Casandra de la Villa Borghese.

A esta lista de E. Langlotz cabe añadir una cabeza de muchacha (¿Artemis?) de mármol, hoy en Bonn, fechada en la segunda 


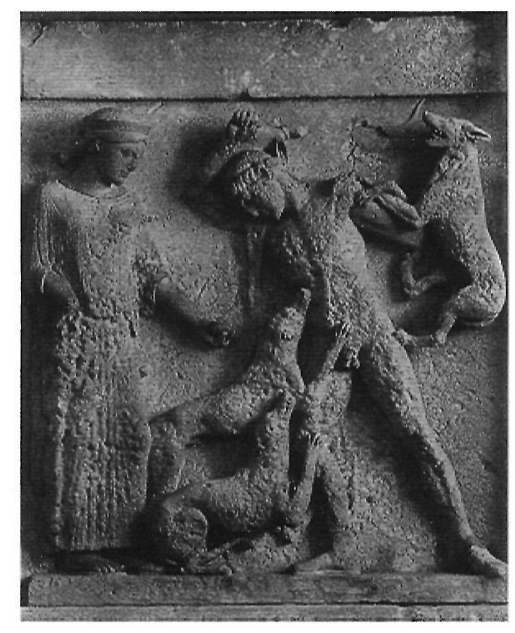

Figura 10: Metopa del santuario de Hera en Selinunte. Atenea y Acteón. Según E. Langlotz.

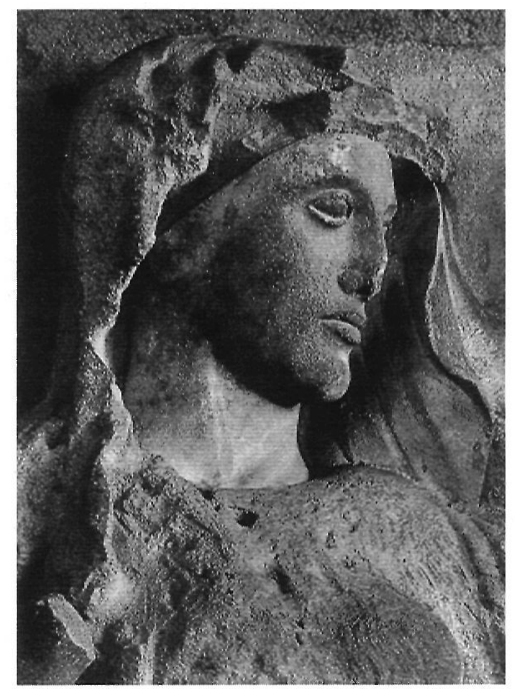

Figura 12: Vista de la figura anterior. Según E. Langlotz.

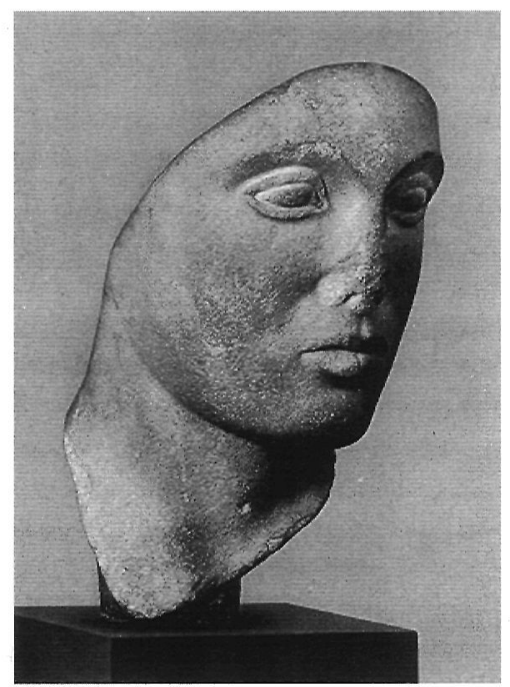

Figura 14: Cabeza femenina de la Metopa del templo de Selinunte. Según E. Langlotz.

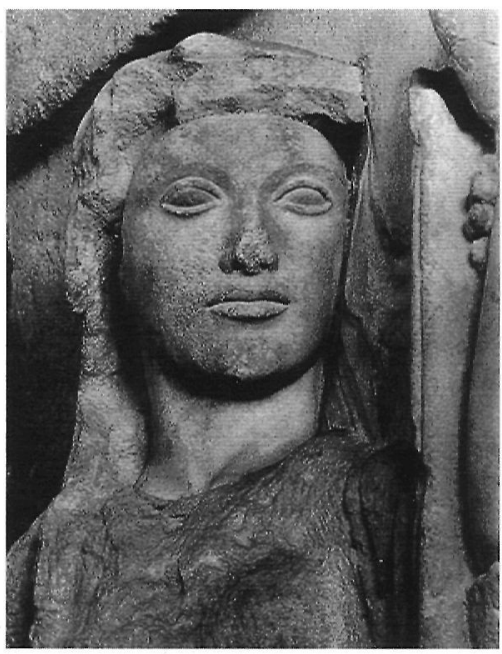

Figura 11: Cabeza de Hera. Santuario de Hera. Metopa. Selinunte. Según E. Langlotz.

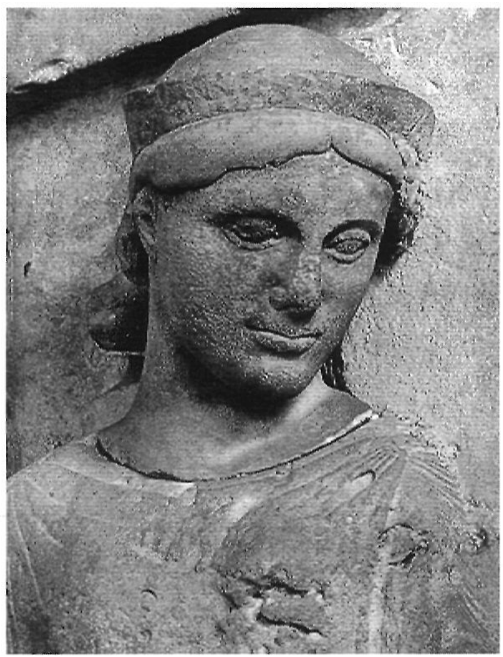

Figura 13: Artemis. Metopa. Santuario de Hera. Selinunte. Según E. Langlotz.

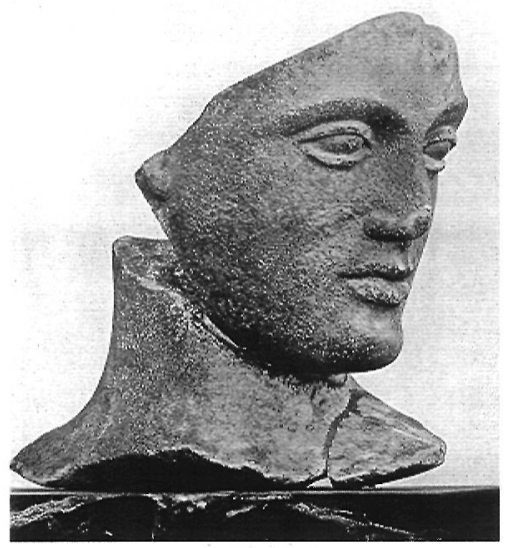

Figura 15: Cabeza de una diosa de la metopa del templo E. de Selinunte. Según E. Langlotz. 


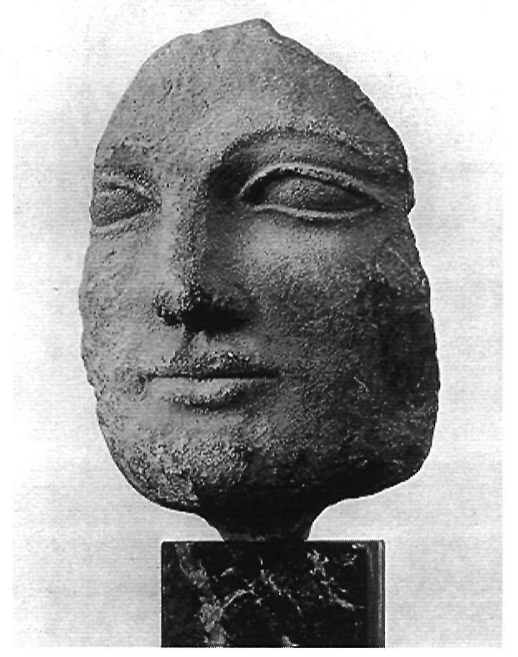

Figura 16: Cabeza masculina de la metopa del templo E. de Selinunte. Según E. Langlotz.

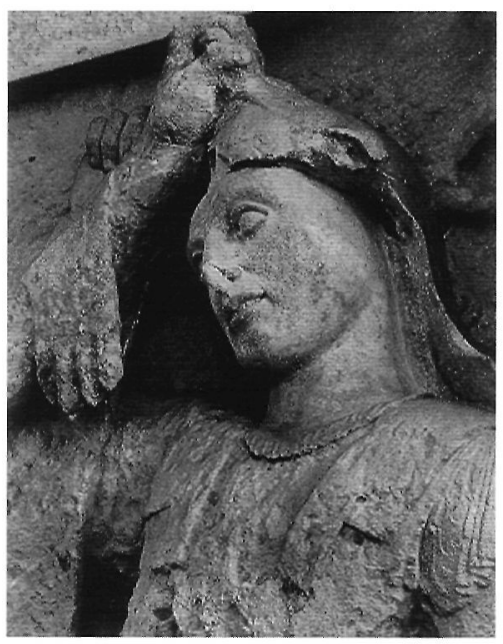

Figura 18: Cabeza femenina del templo E. de Selinunte. Metopa con Heracles y una amazona. Según E. Langlotz.

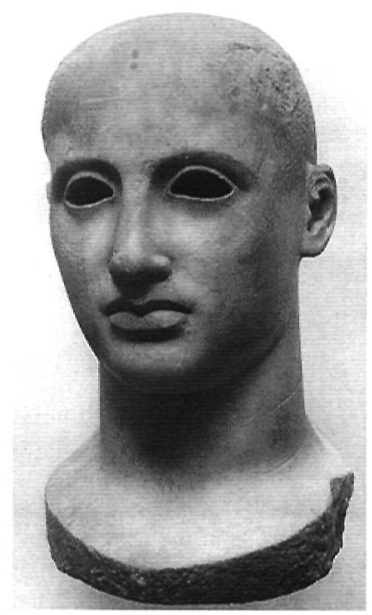

Figura 20: Cabeza de Apolo. Krinisa. Reggio. Final s.V a.C. Según E. Langlotz.

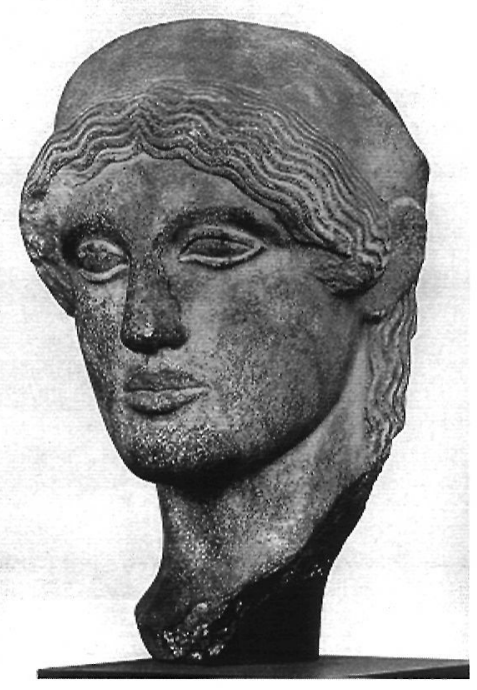

Figura 17: Cabeza femenina del templo E. de Selinunte. Metopa. Según E. Langlotz.

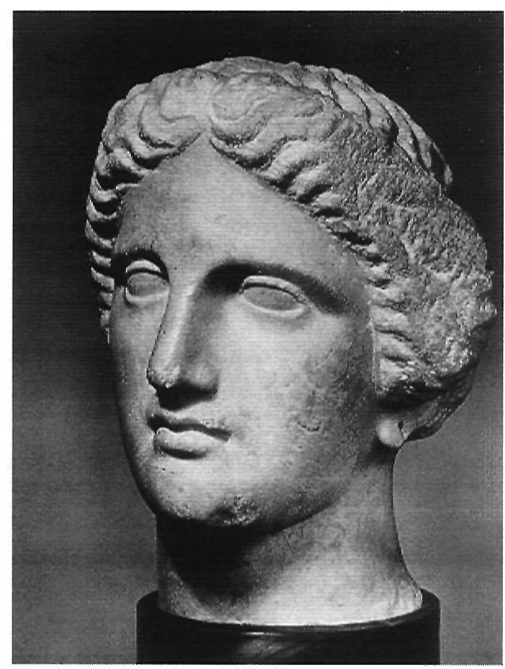

Figura 19: Cabeza femenina. Tarento. Según E. Langlotz.

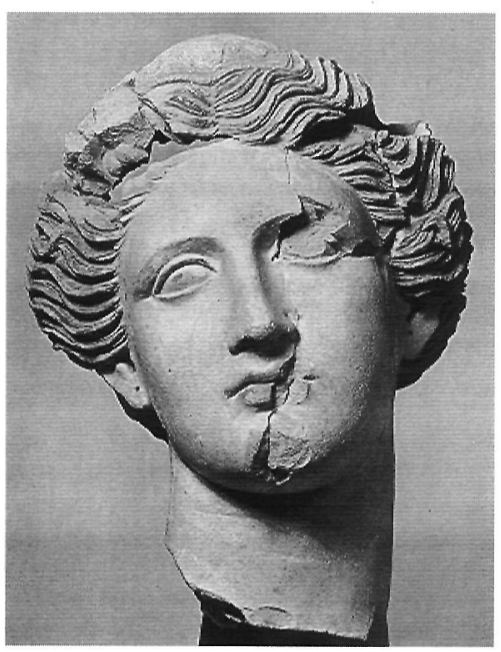

Figura 21: Cabeza de diosa. Terracota. Tarento. Comienzos del s. IV a.C. Según E. Langlotz. 


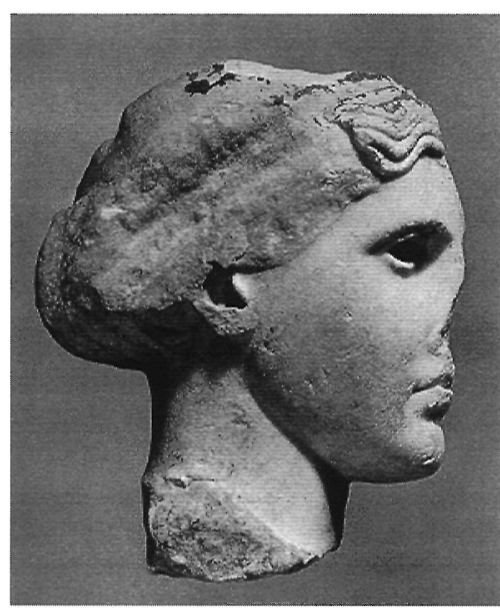

Figura 22: Cabeza de muchacha. Artemis ?.Segunda mitad del s.V a.C. Según E. Langlotz.

mitad del s. IV (Fig. 22), y un Apolo a punto de disparar la flecha con el arco, de la segunda mitad del s. $V$ a.C (Fig. 23) ${ }^{2}$.

\section{ERICH KUKAHN}

El hispanista germano E. Kukahn (Kukahn, 1957, 3-16; Niemeyer, 2001, 608-609, lám. 197c; Almagro Gorbea, 1980, 198-199, láms $\mathrm{CXXXI}$ ), docente de Arqueología de la Universidad de Bonn, hoy injustamente olvidado, publicó en 1957 una terracota rodia del Museo de Ibiza, fechada a mediados del s. $\checkmark$ a.C., que es un buen paralelo para los pliegues del manto de la Dama de Elche y que abre la posibilidad de que el busto de esta dama respondiera a un tipo iconográfico en que el busto fuese de rigor. Las diosas púnicas de terracota (Niemeyer, 2001, 600, lám 184a y b), fechadas entre los siglo $V$ y IV a.C., eran imágenes de la diosa Tanit y de Demeter, datadas estas últimas en torno al 300 a.C. (Niemeyer, 2001, 607-608, lám 196).

La terracota ibicenca (Fig. 24) mide la mitad del tamaño natural de una persona. Fue obtenida a molde y sólo se trabajó el lado frontal. Viste chitón con ancha apóptygma. De los hombros caen los pliegues del chitón. La cabeza está envuelta en un sakkos, al que sujeta una banda formando un rodete. Gruesos y largos bucles en espiral caen de los temporales y cubren las sienes. El rostro es de buenas proporciones. Es un producto puramente rodio llegado por mar. Desde el último arcaísmo se conocen en Rodas prótomos femeninos de gran tamaño, vestidos con chitón e himation sin cubrir los brazos. Un tipo

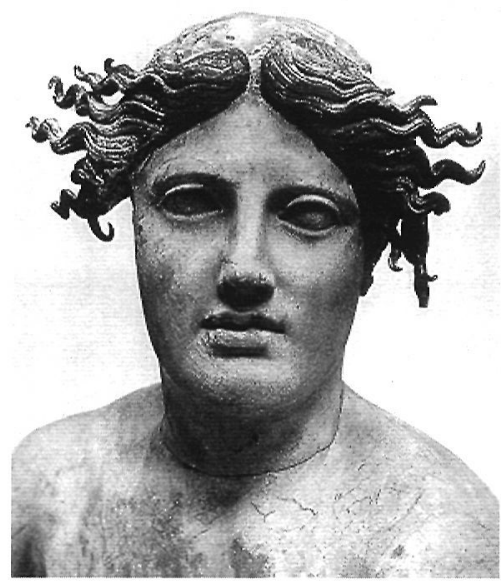

Figura 23: Apolo. Segunda mitad del s.V a.C. Roma. Según E. Langlotz.

precursor de la terracota ibicenca es una procedente del Kameiros. La forma realzada del krédemnon no aparece hasta comienzos del clasicismo, como prueba una terracota rodia hoy en el British Museum.

La terracota rodia de Ibiza debe fecharse después de mediados del s. V a.C. E. Kukahn concede una gran importancia a esta terracota rodia, llegada a Iberia en el s. $V$ a.C., pues el busto, cuya vestimenta corresponde a la de la deidad microasiática de la fecundidad, llega al Occidente no de manera casual, sino a través de la ruta occidental del comercio jonio-fenicio. Posiblemente el busto se enterró en Ibiza por su relación con el culto de Core, debido no al culto cartaginés vinculado con Sicilia (Diod. XIV.77.5), sino con Tiro en el s. V a.C., bajo la acción del componente rodio llegado con la corriente directamente jonio-fenicia. Esto sería una pista básica para solucionar el problema del busto como forma plástica y su desarrollo en el arte ibérico. J. Jiménez (Jiménez, 2002) propone recientemente que la toreútica orientalizante en Occidente es importada. Para J. Alvar es rodia.

Ello atañe, según este autor, y lo creemos una idea muy acertada, al busto de la Dama de Elche. Señala muy acertadamente E. Kukahn que la investigación sobre prótomos de diferentes tipos llevó a ver en ellos casi siempre imágenes de Démeter y de Core y a aceptar la dependencia de tales tipos de modelos sicilianos. A partir del s. IV a.C. aparecen los

\footnotetext{
2 Sobre las metopas de Selinunte puede consultarse: Marconi, 1994 y Papaioannou, 1972, figs. 388-390. Sobre la escultura de Sicilia en época clásica véase: De Miro, 1996, 413-419. Sobre la escultura del s. V a.C. en la Magna Grecia véase: Pugliese Carretelli y Arias, 1990, 299-305, figs. 452-462.
} 


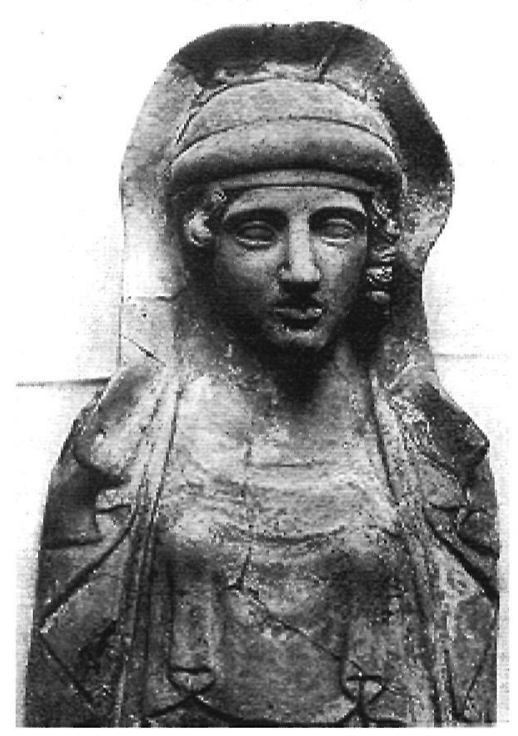

Figura 24: Terracota rodia. Museo de Ibiza. Según E. Kukahn.

thymiateria en forma de busto femenino, que como objeto de culto, se extienden por todo el Mediterráneo; llevan los frutos símbolo de la deidad, algo que se repite también en la cerámica ibérica, destacando entre todos los bustos alados de Tanit. Estas figuras no se emparentan con los ejemplares rodios.

E. Kukahn da una gran importancia a las conclusiones que se desprenden de la dependencia y de la igualdad de formas e indumentaria entre el prótomo rodio de Ibiza y el busto de la Dama de Elche. Los ornamentos y arracadas de oro tienen paralelos y derivaciones en la plástica ibérica. En lo tocante a la forma del prótomo, Kukahn indica que no tiene analogía alguna con otras piezas, pero hoy sabemos que la tiene con el busto hallado en la necrópolis de Cabezo Lucero. Piensa el hispanista germano que la concepción del busto sólo pudo ser introducida como forma religiosa y únicamente a través del mundo griego o grequizado. La Dama, según E. Kukahn, presenta elementos ibero-fenicios que corresponden a una corriente oriental en la que Rodas desempeñó un vivo papel. En Elche, la imagen de la diosa tomó un aspecto de apariencia exótica. Se sustituyó el krédemnon por una alta peineta.

Dentro de la plástica ibérica, la Dama de Elche se aparta de la estatuaria del Cerro de los Santos, que hoy se fecha a partir del s. III a.C. y que en opinión de E. Kukahn es un producto ya estancado, Rodas y Chipre desempeñaron un papel importante en Iberia (Blázquez, 2000, 94-103; 1998-1999, 93-116).
El mismo hispanista (Kukahn, 1967, lám. 373) fecha el busto de la Dama de Elche en torno al 400 a.C. Opina que posiblemente es el busto de una diosa. El vestido sigue la moda griega. El estilo depende del arte de la Magna Grecia. La riqueza de adornos es típica del arte ibero. No es un retrato. La expresión del rostro es griega, pero muchos detalles no encajan con el arte griego.

\section{ANTONIO GARCÍA Y BELLIDO}

La dama de Elche mereció algunos excelentes trabajos de A. García y Bellido. El primero data de 1943 (García y Bellido, 1943). El catedrático de la Universidad Complutense de Madrid volvió a estudiar la famosa escultura ibérica años después (García y Bellido, 1963, 559-574, figs. 489-493; 1980 , 45-52, figs. 5659). Afirma que "la Dama de Elche es digna de aparecer en la segunda mitad del s. $V y$ en un ambiente cultural griego del más puro abolengo, pero no obstante ello, la realidad aconseja fecharla en época más baja, incluso en los siglos helenísticos o helenísticoromanos". Propone una fecha hacia la época de Augusto por las siguientes razones: $1^{\circ}$ el área donde apareció pertenece a una ciudad ya de época romana no ibérica. $2^{\circ}$ esta ciudad fue creada por César a mediados del s. I a.C. $3^{\circ}$ la concepción al modo de imagen retrato en forma de busto excluye su origen griego antiguo, ss. VI ○ V a.C. y apunta, por el contrario, a la época augustea, en la que abundan figuras de busto, como en las estelas de época republicana o del s. I. El suntuoso tocado es de gusto ibérico. Las bullae, anforillas y colgantes obedecen a modas generalizadas a partir del s. IV desde Escitia, por intermediarios griegos o púnicos.

Años antes, García y Bellido (1958, 129132, láms XLV-XLVII) había propuesto una interpretación de gran originalidad, la de que era una versión en piedra de un vaciado del natural.

"Su rígida frontalidad y la impasibilidad del rostro denuncian la existencia de una impronta funeraria precedente, hecha sobre el cadáver. La cosa es perfectamente posible en un ambiente romano y en tiempos de Augusto, si interpretamos positivamente las evidencias históricas y arqueológicas aducidas. De la impronta hubo de obtenerse, primero un vaciado en cera o en yeso y, después, la versión pétrea que ha llegado a nosotros. Ciertas zonas faciales muestran, en efecto, vaguedades o 
convencionalismos de modelado explicable sólo por las necesarias trasformaciones que el escultor en piedra tuvo que hacer del vaciado al tratar de convertir en rostro vivo lo que procedia en la máscara funeraria de una faz muerta. Así, la Dama, ha conservado lo enjuto del rostro, las mejillas planas, la delgadez afilada de la nariz, la asimetría de la cara; pero el escultor ha tenido que 'abrir' por su cuenta los ojos que en la máscara-impronta estaban cerrados y, viceversa, 'cerrar'la boca que en el cadáver, como en su vaciado, estaría probablemente entreabierta. De ahi el modelado convencional de estas partes, a las que deben añadirse el arco superciliar, las cejas y el modo inorgánico de unir el cuello a la barbilla. Advirtamos que otros bustos similares al de Elche, y emparentados con él directamente. como son los del Cerro de los Santos, cercano relativamente a Elche, muestran a veces evidentes rasgos retratisticos aún más fuertes y acusados que los de la Dama. En el caso del busto femenino, con cofia como la de la Dama $n^{\circ} 7542$ del Museo Arqueológico de Madrid, su carácter retratístico es de todo punto indudable. Además, en estas representaciones icónicas, (sean o no evidentes los rasgos individuales) la idea e intención inicial es, en todo caso, la de la imagen-retrato, convertida a veces en un mero símbolo, como tantos otros ejemplos de época plenamente romana podrían enumerarse en España misma.

Las joyas del pecho van dispuestas como en multitud de terracotas griegas, púnicas y greco-púnicas, muy abundantes en Ibiza, en un amplio periodo que llega hasta el cambio de Era, por lo menos. El alto y aparatoso tocado, así como las grandes ruedas que flanquean el rostro son los mismos que vemos en numerosas esculturas españolas coetáneas, que llegan hasta plena época romana imperial, como lo demuestran las terracotas del santuario ibérico de la Serreta de Alcoy, no lejos de Elche. El tocado que exhibe la Dama fué descrito por el griego Artemídoros hacia el año 100 antes de J. C. según nos lo transmitió, un siglo después el geógrafo Strabon.

Reparemos también en el gran hueco que el busto presenta en su reverso, sobre la espalda. Esta concavidad hubo de ser receptáculo de algo.

Al conjugar todos estos datos, resulta sumamente probable la idea de que el busto ilicitano haya sido una especie de recipiente funerario de las cenizas de una dama ilustre que vivió, al modo tradicional indigena, en ambiente romano, el ambiente creado primero por dos siglos de dominio y luego por el establecimiento de los colonos, llevados alli por Augusto. La idea del "canopo» y del retrato en busto, asi como su custodia en una casa urbana bajo hornacina, pudieran obedecer a tradiciones indígenas ancestrales reavivadas y modificadas por las nuevas influencias oriundas de la costumbre romana del retrato vaciado sobre cadáver, característico del ritual funerario que dio lugar a las "imagines maiorum», aun habituales durante el principado de Augusto. La costumbre de conservar los restos mortales incinerados, en una habitación de vivos, en una casa urbana, está atestiguada en España para aquellos mismos tiempos. Es más, aún hay testimonios de aquellas viejas costumbres. Pero, por el momento nos importan, ante todo, los antiguos. En la Lex Coloniae Genetivae luliae sive Ursonensis, la actual Osuna, en la Baetica, se prohibe explícitamente tal costumbre, sin duda porque aún seguía en uso. Por último la vestimenta de la Dama seguiría la tradición ibérica y en el modo de prodigar las joyas el gusto barroco, semibárbaro, de iberos y púnicos y aun de helenos, si no olvidamos numerosas figuritas griegas de terracota profusamente enjoyadas. La forma de prótomo, asi como otros detalles menores que pudieran parecer anacrónicos en tiempos de Augusto, no lo son si pensamos que en estos pueblos marginales es frecuente la hieratización de viejas formas que, a veces, perduran casi invariadas hasta épocas mucho mas recientes. La forma protómica pudo ser en la Dama una reminiscencia de modelos muy anteriores, es cierto, pero pudo pervivir como tipo ritual hasta mucho después. Este es el caso del plegado de paños a 'la arcaica', plegado en el que hay que ver acaso un posible recuerdo, una reminiscencia atávica, del propio de la escultura griega de hacia el año 500 antes de J. C., pero que es simplemente una manera espontánea de representar los pliegues propia de cualquier arte incipiente, inhábil aún para traducir las formas naturales a sus creaciones, hechas, además, no ante modelo -como hoy se hariansino de memoria y en el taller. La rutina puede explicar muchos 'arcaismos' que, en tal caso, serian convergencias casuales, es decir, pseudoarcaismos".

En los años de publicación de estos trabajos, la tendencia general era rebajar mucho la cronología. Un buen conocedor de la Península Ibérica, Julio Martínez Santaolalla, hacía coincidir la buena escultura ibérica con 
el Hierro Ibérico llb, o sea, con la conquista romana (218-29 a.C.) (Martínez Santaolalla, 1946, 95-96).

El lugar del hallazgo de la famosa dama llegó intacto al arqueólogo ilicitano Alejandro Ramos Folqués, que lo fechó en el s. IV a.C. (Ramos Folqués, 1945, 252-260).

Pere Bosch Gimpera, uno de los más grandes prehistoriadores anteriores a la Guerra Civil, compara el busto de la Dama de Elche, por los pliegues del manto, con las estatuas del Llano de la Consolación (Bosch Gimpera, 1961, 73-74). Por la finura de su ejecución podría pensarse que es obra de un escultor griego que trabajase para un señor indigena. Representa, probablemente, una princesa ibérica. Recuerda, por la fecha y por el parentesco, a las obras griegas citadas por R. Carpenter. Rechaza la fecha propuesta por A. García y Bellido.

Giovanni Becatti señala la gran calidad de la Dama de Elche (Becatti, 1965, 244-245) debida a su proximidad al arte helénico y a los modelos de estilo severo. La fecha en el siglo IV a.C.

\section{HERMANFRID SCHUBART}

Director durante muchos años del Instituto Arqueológico Alemán de Madrid y gran conocedor de la arqueología hispana, piensa que no se conocen prototipos directos de la Dama de Elche (Schubart, 1967, 157, 178-100). Los rasgos estilísticos fechan el busto en la mitad del siglo $V$ y acusa influjos de la escultura de Grecia. Reúne una calidad muy alta de arte plástico griego con las formas barrocas de arte ibérico que ponen el marco a la cara dirigida al más allá.

Los detalles del rico adorno, las ruedas, los collares, los colgantes y las fíbulas están presentes, también, en el arte ibérico. Son prueba de una moda que está fuertemente influida por el arte fenicio-tartésico (Sobre el impacto de la religión fenicia en la religión ibera véase: Blázquez, 1999, 175-319; 2003, 324404; AAVV 1999; Ferrer, 2002) pues se vincula con las Joyas de la Aliseda, pero también con la estatua de arenisca de Arsos (Chipre), datada en el s. VI a.C. Tenía una policromía muy viva, y quedan en la actualidad pocos restos de ella.

Los ojos de la Dama de Elche estaban incrustados, como en la plástica griega. La cabeza de Alicante y el busto de la Dama de Elche son ejemplos de una escuela que se desarrolló en la costa levantina, en las provincias de Murcia y Alicante. Fuertes impulsos griegos dieron el empuje y marcaron la dirección, aunque en esta zona no se conocen obras originales griegas; las factorias griegas tampoco se han localizado hasta hoy.

\section{GERARD NICOLINI}

El hispanista francés G. Nicolini dedica pocos, pero importantes párrafos, a la Dama de Elche, a la que considera tan conocida en todo el mundo como la Venus de Milo, la Victoria de Samotracia o la Gioconda (Nicolini, 1973, 84-86). Las fuentes son claras, Rhys Carpenter señaló una imitación del arte griego clásico y sugirió la comparación de su rostro con el del Apolo Chatsworth, gran escultura de bronce descubierta en Chipre, contemporánea de las primeras obras de Fidias, quien realizó para el templo de Zeus en Olimpia, obra del arquitecto Libón de Elis, la estatua de Zeus poco después de la terminación del edificio en 460 a.C. Nicolini plantea la posibilidad de que el artesano que hizo la Dama de Elche tuviera delante una estatuilla de este tipo. El busto, según el hispanista francés, está marcado por la impronta indígena, con un tratamiento de gran calidad. La mitra se documenta en los bronces de Despeñaperros, contemporáneos o de fecha poco anterior. Quizá fuera de origen oriental esta prenda, pero arraigó mucho en la Península Ibérica. El tratamiento del velomanto, que cubre la espalda con pliegues geométricos, es frecuente en la escultura del sudeste. Sobre este vestido se superponen un segundo manto y una túnica. Los tres vestidos figuran en las esculturas arcaicas y de época media, también en escultura de piedra. Las grandes bullae se encuentran en el Tesoro de la Aliseda. Las grandes ruedas para recoger el pelo aparecen también en tres o cuatro esculturas del Cerro de los Santos. No se puede hablar de un arcaísmo que se mantenga. El relativo esquematismo del vestido indica una cierta evolución en relación con el pleno arcaísmo. Nicolini fecha el busto en el s. V a.C. Se ha interpretado la Dama de Elche como una estatua de culto, un exvoto o el retrato de una princesa. Para G. Nicolini es un busto funerario.

\section{RAFAEL RAMOS FERNÁNDEZ}

Este autor ha dedicado varios e importantes trabajos a esta pieza excepcional (Ramos, 1995, 123-133; 1997) que conservaba restos de policromía roja, azul y blanca. El busto 
destaca, según este arqueólogo, buen conocedor de la cultura ibérica, por la personalidad de sus facciones. La parte mejor lograda es la cara. Todo su mundo está en la profundidad de la apariencia silenciosa de una condición humana que trasciende a lo divino, según sus palabras. Los rasgos de la cara son de un modelado vivo. Piensa R. Ramos que el tocado fue el descrito por Artemidoro hacia el año 100 a.C. (Str. III.4.17). Los rodetes han aparecido en Extremadura y en el Cigarrelejo. El atuendo refleja la moda ibérica de la época. La Dama tiene sus paralelos más próximos en la indumentaria femenina etrusca, caracterizada por complejos tocados y por las grandes joyas. Los modelos responden a tipos de área subitálica. Las joyas son del tipo orientalizante, que aluden a la llegada a Occidente de una corriente del este mediterráneo, matizada por creaciones de la periferia griega, adaptadas en Iberia a las representaciones de mujeres, que prestaron sus rasgos para permitir el retrato de la divinidad, ya que únicamente estos retratos de sacerdotisas se engalanaron con grandes bulas, que aparecen en el arte etrusco (Cristofani y Martelli, 1983, 307-308, figs. 221-222, de Vulci fechada en torno al $350 ; 315$, figs. 260-261, de Vulci y de procedencia desconocida de la misma fecha; Cateri, Fiasci 1984, láms IV, XVI).

La Dama de Elche, enormemente enjoyada, responde a las diosas de la fecundidad, como Afrodita, según el himno homérico a la diosa (II.5-11). La existencia del hueco cree que sirvió para colocar ofrendas. Según este historiador, la escultura fue concebida como busto. Recuerda que la Démeter Thesmophoros venerada en Tebas estaba representada sólo por la parte superior de la imagen (Paus. IX.16.5), y en el santuario del bosque sagrado de Pirea, las imágenes de Demeter, Core y Dionisos estaban representadas únicamente por rostros. Menciona R. Ramos los pebeteros en forma de bustos, claro objeto de culto, que son los bustos alados de Tanit, a juzgar por sus atributos. Según este autor, la concepción del busto correspondería a una forma cuya difusión se extendió por todo el mundo mediterráneo grequizado. En opinión de R. Ramos, la Dama de Elche es, sin duda, el retrato de una mujer real. Recuerda el autor, a este respecto, un texto de Pausanias (II.38.7) que menciona estatuas de mujeres, sacerdotisas de la diosa. En Chipre, la diosa se confundía con su sacerdotisa. Esta misma asociación se daría también en Iberia. La dama debió ser el retrato, por lo tanto, de una sacerdotisa de la Dama de Elche. La Dama de Elche puede asociarse a modelos rodios fechados en la segunda mitad del s. V a.C.. Su fecha oscila entre los últimos años del s. $V$ y la primera mitad del s. IV a.C.

\section{PILAR LEÓN}

Esta catedrática de la Universidad de Sevilla, gran especialista en escultura clásica (León, 1988, 66-69) considera que la Dama de Elche carece de estructura orgánica, pues ha sido concebida como un armazón o maniquí sobre el que se monta un complejo deslumbrante. Contrasta la indefinición amorfa de la mitad inferior (el busto) y el desarrollo monumental del tríptico de la parte superior (la cabeza), al igual que la Gran Dama Oferente del Cerro de los Santos y otras damas de este yacimiento. Según esta autora, la rigidez del cuello y la carga de hombros no obedecen sólo al hecho de sostener un peso abrumador (tocado, diadema, pectoral) sino que, igualmente, es reflejo de las dificultades. El esquema iconográfico alcanza en este busto máxima originalidad, que tiene amplia difusión por todo el Mediterráneo. Son elementos característicos: a) la vestimenta, dos túnicas y un manto griego amplio; b) las joyas espléndidas; c) las ruedas. Para todo ello hay paralelos por todo el Mediterráneo, con frecuencia púnicos o cartagineses.

Piensa $P$. León que el pectoral del colgante es característico de diosas representadas en terracotas de Agrigento, en torno al 500 a.C., de donde pasó a la coroplastia púnica de Ibiza. Recuerda la autora el citado trabajo de J. Jacobsthal y cómo los grandes rodetes, las rosetas, las flores o las cintas, se trataban para Jacobsthal de pelucas para actos de culto, como también reconoce $S$. Besques al tratar de una terracota de Tebas. Señala $P$. León que en esta terracota se observan los primeros signos de idiosincrasia indígena, patentes en el canon facial inspirado en el ideal de severidad propio de la alta época clásica, pero estilizado a la manera ibérica. A ello se añaden las preferencias de los escultores iberos, como la oblicuidad de los ojos, las cejas arqueadas distantes de los párpados y los labios finos. Queda bien patente el sentido de la ostentación, del boato y del hieratismo. La impronta ibérica se advierte en el predominio de lo decorativo sobre lo funcional y en la superficialidad de lo modelado. Es carac- 


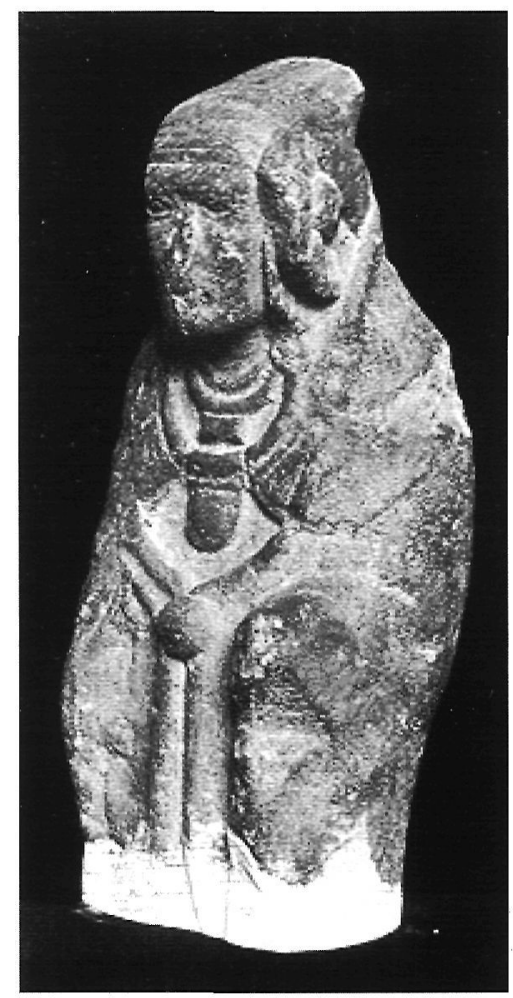

Figura 25: Escultura del Cerro de los Santos. MAN. Según A. García y Bellido.

terística la manera de tratar los pliegues, al igual que en la Gran Dama Oferente. Duda la autora de si fue un busto o una estatua de pie. La figura erguida tiene paralelos en las esculturas del Cerro de los Santos y en las terracotas. Como la Dama de Elche iba pintada de rosa, la impresión era diferente de la que hoy hace en el espectador.

Martin Almagro Gorbea, buen conocedor de la Prehistoria hispana, parte de la idea de que la Dama de Elche es una obra maestra de la escultura ibérica, de clara influencia griega (Almagro-Gorbea, 1994, 544-545).

\section{JOSÉ MARIA BLÁZQUEZ}

Piensa este autor que los distintos elementos de la Dama de Elche están perfectamente documentados en bronces y esculturas ibéricos (Blázquez, 2000, 134-146). Hoy día se sabe que la escultura ibérica es anterior a la conquista cartaginesa de la Península Ibérica, o sea, al 236 a.C. Se prescinde de la descripción del busto, ya que al comienzo de este trabajo se ha incluido una, magnífica, debida a la pluma de Antonio Blanco Freijeiro.
El busto iba todo él pintado, al igual que los exvotos del antiguo Partenón de Atenas (Richter, 1968), datado en época de los Pisistrátidas (561-510 a.C.) y destruido por los persas en 480 a.C. Las figuras del frontón de Egina iban todas ellas repintadas en color azul añil (Papaioannou, 1972, figs. 85-86, 123, fechadas en 490-480 respectivamente; fig. $337-$ 343 , templo de Apolonia datado entre 500-480. Boardman, 1985, figs. 206. 1-6). Difícilmente a un artesano del s. XIX se le hubiera ocurrido pintar el busto de la Dama de Elche, de ser cierta la fecha propuesta por F. Moffit (Moffit, 1994). La forma posterior de la cabeza rematada por una tiara se repite en dos esculturas del Cerro de los Santos (García y Bellido, 1963, 483, fig. 385; 505, fig. 410). Una de ellas lleva grandes ruedas laterales sobre los oídos (Fig. 25) y tres collares, de uno de los cuales cuelga una gran bulla, como en la Dama de Elche. La Dama de Cabezo Lucero, de la que se habla en este mismo trabajo, lleva también tres collares con porta-amuletos. Grandes ruedas le cubren las orejas.

\section{Diadema}

La frente de la Dama de Elche va cubierta por una diadema. Los fenicios introdujeron esta joya en Occidente, que gozó de gran aceptación entre las damas iberas. Los micénicos usaban ya diademas en el s. XVI a.C., que son frecuentes en sus círculos de tumbas y que en origen proceden de Oriente (Musti et alii, 1992, 232, fig. 1). También se usaban en el mundo griego (Musti et alii, 1992, 253, fig. 96 de Delfos; 259, fig. 116 de Puglia; 278, fig. 150) y etrusco (Cristofani y Martelli, 1983, 305, fig. 211 de Spina, primer cuarto del s IV a.C.).

Fueron muy utilizadas en el mundo griego arcaico; diadema de electron de Rodas, fechada en los siglos IX-XII a.C.; diademas áureas del Camiro, del siglo VIII a.C.; las tres diademas procedentes de Atenas; ejemplares de Corinto y de Efestia de la misma fecha, y de Chipre. Los prototipos de las diademas griegas proceden, seguramente, de Asiria, como lo indican los relieves de Shanshi-Adad V (823811 a.C.) o el relieve con escenas de cacería de Assurbanipal (668-633 a.C.) procedente de Nínive. Otras diademas se documentan en Sichem, en el siglo XII a.C., en Palestina.

Las Sagradas Escrituras (2 Sam. 1, 10; 2 Re., 11, 12; Is. 62, 3) mencionan también el uso de las diademas por los judíos.

Diademas iberas famosas, además de las de La Aliseda, son la del Cortijo de Evora 


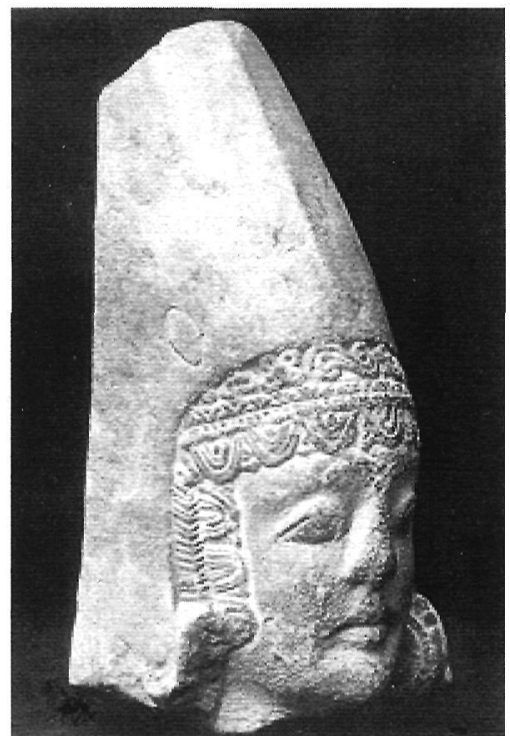

Figura 26: Cabeza del cerro de los Santos. MAN. Según A. García y Bellido.

(Sanlúcar de Barrameda, provincia de Cádiz) decoradas con máscaras de Bes, fechada en la segunda mitad del siglo VI a.C., la - probablemente- de Jávea (Alicante) del siglo IV a.C.; la de Crevillente (Alicante), de fines del siglo VII a.C., que es una placa semejante a la que exhibe la Dama de Elche (Blanco, 1956, 1517; Blázquez, 1988, 220-221; Nicolini, 1990, 483-496, nos. 240-246). Según Nicolini las diademas han aparecido en la Península Ibérica en Sanlúcar de Barrameda, Aliseda (dos), Jávea, Crevillente, Almuñécar y Villaricos.

Una diadema ciñe la frente de la llamada Gran Dama Oferente del Cerro de los Santos, (García y Bellido, $1963,475,496-497$, figs. 378-381; 1980, 35, figs. 38-38; Schubart, 1967 , $159,162,165,168)$, cuyo vestido muestra elementos idénticos a los de la Dama de Elche, como son el pasador en $\mathrm{T}$, dos túnicas debajo del manto, tres collares (aquí sin portaamuletos), y las ruedas, de menor tamaño, sobre la clavícula en vez de a la altura de las orejas, como las de la Dama de Elche. Estos tres detalles no podrían aparecer en la dama de Elche si, como se ha dicho, fuera una obra del s. XIX. Tres damas sedentes del Cerro de los Santos portan diademas en la frente (García y Bellido, 1963, 481-482, 507, figs. 382-383, 418,421 ) (Fig. 26). A estas damas hay que sumar otras tres cabezas procedentes, también, del Cerro de los Santos. En dos de ellas las diademas van decoradas con motivos espirales, como las de Jávea y las de las damas oferentes del Cerro de los Santos.
Una de las cabezas, la número 7.510 , lleva unos discos a la altura de la boca, que ya A. García y Bellido equiparaba a las grandes ruedas de la Dama de Elche. Estas últimas cabezas llevan una especie de pirámide sobre la cabeza, cubierta por el manto. Por el interior se enroscaban el pelo con algún tipo de soporte, citado por Estrabón (III, 4, 17), quien toma el dato del gramático Artemidoro.

\section{Tiara}

La forma de rematar la parte alta posterior de la cabeza con una tiara se repite idéntica en otras esculturas ibéricas, entre ellas en dos que son paralelos exactos para el busto de la Dama de Elche; una de ellas, la aparecida en el Cerro de los Santos (Albacete) (García y Bellido, 1963, 483, fig. 385) lleva también unas grandes ruedas laterales a la altura de las orejas, tres collares sobre el pecho y un gran porta-amuletos en forma de lengüeta, elementos todos ellos que se encuentran en el busto de la Dama de Elche. Esta excepcional escultura se conserva en el Museo Arqueológico Nacional de Madrid. El segundo paralelo al que nos referimos es el citado busto de Cabezo Lucero.

\section{Ruedas de pelo}

El origen de este adorno hay que buscarlo en el Mediterráneo oriental, según la documentación ya citada aportada por P. Jacobsthal. Aparecen también en la Dama de Cabezo Lucero y en varias esculturas del Cerro de los Santos, como la mencionada Gran Dama Oferente y las dos citadas con tiara. También en la diadema y en exvotos de mujeres hallados en Despeñaperros (Fig. 27) (Nicolini, 1977, 134137, 140, 284-285; 1973: pl. III: d) y en Alcoy (García y Bellido, 1963, 471, fig. 370)

\section{Otros adornos}

Las placas que adornan los lados del rostro de la Dama de Elche, decoradas con volutas de las que cuelgan los tubos, deben ser el mismo adorno que se encuentra a ambos lados del rostro de las dos cabezas citadas del Cerro de los Santos, con diadema y manto sobre la cabeza. Aquí este motivo decorativo es alargado y el dibujo una serie de lengüetas superpuestas.

Las damas ibéricas frecuentemente recogen el cabello con un manojo de trenzas, lisas o sogueadas, que caen a ambos lados del rostro; a veces, el extremo muestra un remate o adorno con forma de anforilla. Baste recordar 


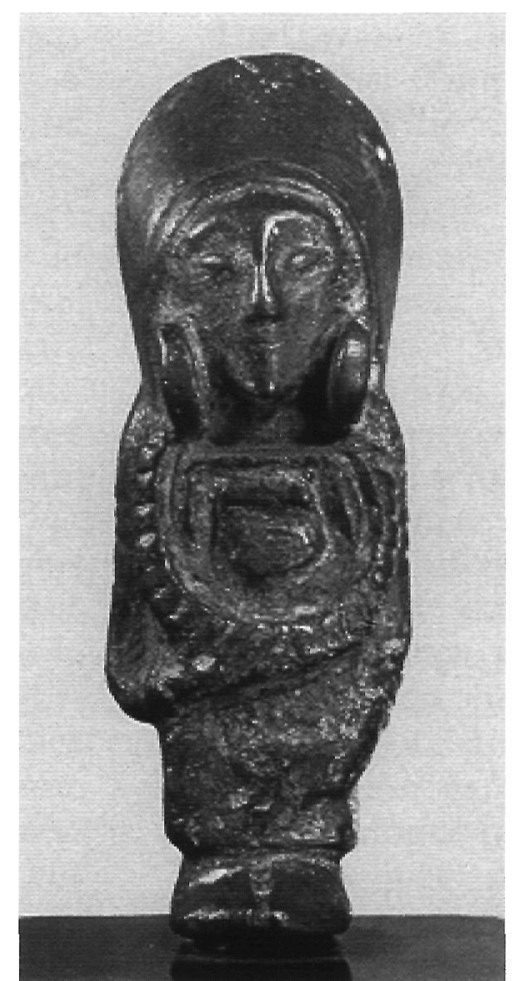

Figura 27: Exvotos de Castelar de Santisteban. Museo Provincial de Barcelona. Según G. Nicolini.

una dama oferente del Cerro de los Santos (número 7.628), con un haz de tubos de pelo liso, sujetados por dos cintas transversales. Esta cabeza muestra la frente cubierta por una diadema de volutas. Una segunda escultura de dama oferente, la número 7.589 , hallada en el mismo santuario albaceteño, recoge el cabello en haces sogueados dispuestos como siempre a ambos lados del rostro; de forma similar lo hacen la esposa del grupo escultórico procedente también del Cerro de los Santos que representa a un matrimonio de oferentes (García y Bellido, 1963, 491, fig. 396), la dama número 7.542 , de la misma procedencia (García y Bellido 1964, 502, fig. 412) y una cabeza del mismo lugar en la que el haz de cabello, con dibujo en espiral, termina en anforiscos. Los ejemplos se podrían multiplicar. Los aquí citados son paralelos muy exactos para este detalle del rostro de la Dama de Elche.

El borde del manto en el busto de la Dama de Elche va ribeteado por una cinta de pliegues sesgados a ambos lados, que se documenta en otras esculturas femeninas del Cerro de los Santos ya citadas, como la Gran Dama Oferente.

\section{Collares y amuletos}

La Dama de Elche, como ya se indicó, lleva adornado el pecho con tres collares compuestos de elementos esferoides. Del inferior cuelgan porta-amuletos lisos en forma de lengüeta, y de los dos superiores, portaamuletos anforiformes.

Las damas representadas en los exvotos ibéricos llevan frecuentemente collares sobre el pecho, en número variable. Unas veces cuelgan de ellos porta-amuletos y otras veces no. (García y Bellido, 1963, 482, fig. 384; 485, fig. $387 ; 486$, figs. 388,390 , etc.). De particular interés para los fines de nuestro trabajo son varios exvotos ibéricos procedentes de los santuarios de Despeñaperros, con collares de los que penden porta-amuletos en forma de lengüeta, como la orante envuelta en su manto, fechada en el siglo VI a.C., del Collado de los Jardines.

Esta magnífica pieza adorna su pecho con collares, igual que la que G. Nicolini considera sacerdotisa (Nicolini, 1963, 134-135; $140-141 ; 184-188 ; 1977,78-79)$, de la misma procedencia, con un solo collar al cuello y los brazos plegados al cuerpo. Tres collares sogueados lleva la reiteradamente citada Gran Dama Oferente del Cerro de los Santos, al igual que la dama oferente número 7.629. Hasta cinco collares, ninguno de ellos con portaamuletos, como en otras anteriores, cubren el pecho de una dama oferente, la número 7.638 (García y Bellido, 1963, 486, fig. 388). Todas proceden del Cerro de los Santos.

Otras veces, las damas de este santuario se adornan con un solo collar sin portaamuletos, lo que es frecuente en estos exvotos, como la mencionada esposa-oferente. Alguna vez los collares son dos, como en la dama del mismo santuario albaceteño, número 7.621 (García y Bellido, 1963, 487, fig. 392). Todos estos collares carecen de porta-amuletos. No así los citados paralelos de forma de lengüeta y de Cabezo Lucero.

Los porta-amuletos de forma de lengüeta los introdujeron los fenicios, y están presentes ya en el Tesoro de La Aliseda. G. Nicolini, al observar que sólo los usan las mujeres, los interpreta como propios de sacerdotisas (Nicolini, 1990, 441-452, lám 120-125; sobre los collares, 433-478, láms 119-160). Se conocen varios porta-amuletos, a veces ricamente decorados con motivos florales y geométricos, y con fino granulado, estudiados por A. Blanco, G. Nicolini y por mí (Blázquez, 1988, 223-224); han aparecido en Almuñécar (Granada), datados en la primera mitad del siglo $\checkmark$ a.C., y en Extremadura, a comienzos del siglo $\checkmark$ a.c. 
Las perlas esferoides de los tres collares superiores de la Dama de Elche, que serían metálicas, existen en la realidad. Han aparecido en Evora, de la primera mitad del siglo VI a.C., y en Andalucía, del siglo IV a.C. Los amuletos anforiformes de la Dama de Elche se repiten, más estilizados, en la Dama de Baza (Granada), obra del siglo IV a.C. y hasta la aparición de esta obra hace poco más de veinte años no existía ningún otro ejemplo en España. Por tanto, habría sido imposible su falsificación en el siglo XIX. Ambas damas llevan sobre el pecho los dos mismos tipos de porta-amuletos.

Todos los elementos del busto de la Dama de Elche son, pues, bien conocidos en el arte ibérico, y no ofrecen ninguna novedad, ni siquiera en su utilización conjunta. El conocimiento superficial que se tenía del arte ibérico a fines del siglo XIX, descarta totalmente una falsificación en el busto de la Dama de Elche. Hasta los más mínimos detalles, como la cinta sujeta por el pasador en $\mathrm{T}$, los pliegues del manto sobre el pecho, los porta-amuletos en forma de lengüeta con el borde resaltado, los collares con cuentas esferoides, las ruedas del pelo, el empleo de garfios, y, en fin, el uso de la diadema delante del velo, tienen paralelos exactos en el arte ibérico, pero tales detalles no podían falsificarse en el siglo XIX porque no se conocian: yacimientos y piezas han sido descubiertos $y$ estudiados en el siglo $X X$. Ningún detalle del tocado de la Dama de Elche está ausente en el arte ibérico en bronces y en esculturas de piedra. Es absolutamente imposible que a un artesano de fines del siglo XIX se le ocurriera esta combinación de elementos.

\section{Finalidad, estilo y fecha}

La finalidad del hueco que tiene la Dama de Elche en la espalda ha sido muy discutida por los arqueólogos. Se pensó hace años que la Dama de Elche estuvo inspirada en terracotas, y que como a éstas, durante el proceso de cocción, se les hacía un hueco en la espalda, este detalle se copió automáticamente en el busto, sin que aquí tuviera utilidad alguna.

Hoy día, después del descubrimiento de la Dama de Baza, que llevaba las cenizas dentro de la escultura, y de la Dama de Cabezo Lucero, se supone que tal orificio estaba destinado a depositar en el interior de la escultura las cenizas y los restos de la cremación del cadáver. Los etruscos, desde antiguo, utilizaban frecuentemente esculturas para conservar las cenizas de los difuntos
(Sprenger y Bartolini, 1983, 82-83, figs. 14-15, fechadas en los ss. VIII y VII a.C. Bianchi Bandinelli y Giuliano, 1973, 185-192, figs. 213216, 218, 224).

A. Blanco aceptó en su estudio de la Dama de Elche la tesis de su maestro, que relacionaba el rostro de la Dama con los rostros de las figuras femeninas del templo de Hera en Selinunte (Sicilia) (470-450 a.C.) y concretamente con el de la propia Hera, la esposa de Zeus. A. Blanco acepta que su autor pudo haberse formado en ésta o en la escuela de Siracusa, si es que a ésta pertenece la cabeza de Atenea del Museo Vaticano, muy parecida a la Dama de Elche en la forma de la boca, de los ojos y en el semblante facial. A. Blanco no descarta que el artista fuera griego, lo que nos parece probable. Ya E. Langlotz (Langlotz, 1966) señaló el influjo del arte focense en la escuela ibera del levante, y nosotros lo hemos propuesto también para la de Obulco, tesis esta última aceptada por los mejores especialistas en escultura griega de Alemania (Blanco, 1966, 533-618; Blázquez, 1992, 387-421; Blech, 2001, 622-624, láms. 221-223; González Navarrete, 1987).

La Dama de Baza, con las cenizas del muerto dentro de la escultura, es un buen ejemplo de que entre los iberos también existió la costumbre de utilizar urnas con forma humana como osario.

El minucioso estudio estilístico a que sometió A. Blanco el busto de la Dama de Elche con ocasión de publicar la escultura antigua conservada en el Museo del Prado, donde entonces se conservaba la famosa Dama, (Blanco, 1957, 130-133 láms. LXXVII-LXXVIII), le llevó a la conclusión de que era obra de la primera mitad del siglo $\mathrm{V}$ a.C., fecha que es la sugerida también por nosotros y por otros autores. La fecha propuesta en cambio por la excavación efectuada por el arqueólogo Alejandro Ramos Folqués, dueño del yacimiento y buen conocedor del lugar, es un siglo posterior.

El artista, según A. Blanco, hizo su aprendizaje en Italia o en Sicilia, seguramente como mercenario, pues aquí ya aparecen mercenarios iberos a partir del 480 a.C., fecha de la batalla de Himera. E. Langlotz escribió en 1966: "tiene un semblante cuyos más exactos paralelos se encuentran en lo jónicooriental, sobre todo en algo que caracteriza mucho su fisonomia: la gran distancia que separa a las cejas de los párpados superiores, los cuales están reforzados por una línea incisa. 
Este rostro, aún hoy fascinante, está hieráticamente petrificado, pero no oculta sus prototipos orientales" (Langlotz, 1966, 40).

La Dama de Elche pertenece a un grupo de imágenes de diosas en piedra al que pertenecen, según Blanco, las siguientes: la Perséfone de Elche con ramo de adormidera; la estatua funeraria del Cabecico del Tesoro en Verdolay; la estatua funeraria del Llano de la Consolación. En todas ellas la influencia del arte griego es manifiesta, traída por los griegos focenses de Marsella. En Etruria se establecieron artesanos griegos, hidrias de la segunda mitad del s. VI a.C. de Caere y esculturas en relación directa con Samos y con las colonias jonias hasta los comienzos del s. V a.C. (Bianchi Bandinelli, 1973, 165-166). En la Península lbérica pasó seguramente lo mismo.

A. Blanco, al referirse a la escultura de Obulco, sugiere que pueden ser también imágenes de dioses las siguientes: una dama estática; el despotes theron flanqueado por dos cápridos; la dama acompañada por uno o dos niños pequeños; la dama con serpiente al hombro, atributo de las diosas aladas de Elche. A estas esculturas cabe añadir la dama alada, posible imagen de Astarté delante de una esfinge, de Elche, la de Cabezo Lucero y la Astarté de Pozo Moro (Marín Ceballos, 20002001, 183-196).

El carácter de diosas de la muerte queda bien patente en las imágenes del Cabecico del Tesoro, del Llano de la Consolación, de Cabezo Lucero y en la Astarté de Pozo Moro, por haberse recogido en necrópolis, y la Perséfone de Elche y las diosas de Obulco, por pertenecer a monumentos funerarios, y la Astarté de Elche por encontrarse delante de una esfinge, animal de claro carácter fúnebre.

Estatuas funerarias son bien conocidas en Etruria. Baste recordar una fechada entre los años 540-520 a.C. de Chiusi (Bianchi Bandinelli y Giuliano, 1973, 193, fig. 225).

\section{La Dama de Elche, imagen de diosa funeraria}

Un problema que ha planteado la investigación moderna es a quién representaba el famoso busto, que ha llegado a nosotros cortado por la parte inferior. Hay dos posibilidades: o bien estaba entronizada, al igual que las damas del sudeste, como la encontrada en el Llano de Nuestra Señora de la Consolación (Albacete) (García y Bellido, 1963, 495, fig. 400), o bien estaba de pie, como la Gran Dama Oferente del Cerro de los Santos, tal como propone J. Pijoan. Me inclino a pensar que era un busto como la Dama de Cabezo Lucero, de carácter funerario. No podia estar entronizada, pues no hay huellas en la espalda de estar adosada a un trono (González, 1997, 329-343). Creo que se trata de una diosa como la Dama de Baza, que sería una imagen de Tanit, que en Cartago era una diosa infernal, como lo prueba la tapa del sarcófago con la imagen de Tanit alada, según la atinada interpretación de M. E. Aubet (Aubet, 1958, 6182). En la misma ciudad de Elche ha aparecido una imagen de Tanit alada. En la Elche romana (I/ici) se veneraba a Juno, equivalente a la Tanit cartaginesa, y a la Astarté fenicia (Ramos, 1988, 96-97), en ambos casos la misma divinidad de la fecundidad, según testimonio de un semis acuñado en la ciudad en época de Augusto, que representa un templo tetrástilo con la dedicatoria a Juno. En la cerámica de Liria (Valencia), fechada en el siglo II a.C., se pintó frecuentemente la imagen de una diosa alada rodeada de animales, peces y plantas como atributos.

El hecho de que se enterrara en la Antigüedad protegida por piedras indica que se trata de una diosa, no de un simple particular.

Toda la escultura ibérica es de carácter religioso, y son imágenes de diosas, exvotos, funerarias, al igual que lo fue la etrusca hasta la época helenística (Sprenger y Bartoloni, 1983; Steingraber, 1985; Cristofani, 1985; Bianchi Bandinelli y Giuliano, 1973; Torelli, 2001) y como fue también la griega (Zevi, 1990; Langlotz, Himmer, 1963; Papaiannou, 1972; Richter, 1968; Richter, 1970). La Dama de Elche no es una imagen para ser depositada en una cella, como las imágenes de las diosas de Grecia, pues no hay cellas en los santuarios iberos, al contrario de lo que ocurre en los griegos (Robertson, 1982).

La Dama de Elche no puede ser la imagen del templo de la ciudad, que era un templo fenicio, como acertadamente ha demostrado el excavador R. Ramos (Ramos, 1995) y nosotros. Los templos fenicios carecían de imágenes de culto, al igual que el Heracleion Gaditano. Sed nulla effigies simulacrave nota deorum, escribe Silio Italico (Pun. III.3). Los santuarios ibéricos eran los lugares sacros para depositar los exvotos, como lo fueron los primitivos santuarios etruscos y romanos, como los depósitos votivos del Lapis Niger del Foro Romano, 550-530 a.C.; del Brolio en Val di Chiana, 600-480 a.C.; de Fonte Veneziana (Arezzo), 530-470 a.C.; de Falterona, 500-325 
a.C.; de Monte Acuta Ragazza (Grizzana, Bolonia), 480-450 a.C.; de Marzabotto, 480-450 a.C. y del Santuario de Villa Cassarini de Bolonia, 500-450 a.C. (Cristofani, 1985, 73276); del antiguo Partenón de Atenas, construido por los Pisistrátidas (561-510) y destruido por los persas en 480 a.C. (Richter, 1968; Richter, 1970); del Heracleion de Samos (Freyer-Schanenburg, 1974; Jantzen, 1972); y del santuario de Ayia Irini, ss. VII-VI a.C. (Karageorghis, 1982, 142, fig. 108. Las actitudes de los exvotos en Iberia, en Etruria y en Atenas eran muy parecidas. Eran similares a los de los tesoros griegos de Delfos, como el de los Sifnios, del 525 a.C., o el de los atenienses (Papaioannou, 1972, 524-526, figs. 297-303).

Las esculturas de Elche no pueden ser exvotos de un templo, sino que muy probablemente, como ya apuntaba Blanco (Blanco, 1981, 50-519), pertenecen a un heroon de la segunda mitad del s. V a.C. Los guerreros estarían cumpliendo un ritual funerario agonístico (Blázquez, 1999, 341-362; Blázquez 2001, 315-323), como los de Obulco (González Navarrete, 1987; Blanco, 1996, 533-615; Blázquez, 1992, 387-421; Blech, 1992, 622624, láms 221-223), de Huelma (Molinos, 1998) y de Osuna (Blech, 1992, 626-627, lám. 625628). La Dama de Elche podría pertenecer a un heroon de una necrópolis, pues imágenes de diosas aparecen en los heroa ibéricos. La Dama de Elche fue ocultada a propósito, lejos de su primitivo emplazamiento.

Se han dado varias causas para la destrucción de estos heroa, como cambios de la religiosidad ibera, algo que sin embargo no se documenta en los santuarios ibéricos, donde existe una gran continuidad; se habla también de "revueltas sociales internas contra la aristocracia dirigente", de las que tampoco queda rastro alguno en el interior de las ciudades. Las ciudades iberas no estaban gobernadas por oligarquías, siempre lo estuvieron por monarquías (Caro Baroja, 1971, 101-159). En Grecia, en los ss. V y IV a.C., las revueltas sociales llevaron al establecimiento de oligarquías o democracias (Sta. Croix, 1988, 333). En Sicilia hubo revueltas sociales en los ss V-IV a.C. (Blázquez, 2000, 287-318). En Sicilia gobernaron tiranias. Tampoco mencionan las fuentes antiguas tiranos en Occidente. No existió preparación social para ellas.

La sociedad ibera, por lo que podemos barruntar, estaba mucho más atrasada que la griega y no había caldo de cultivo para estas revueltas. Los problemas sociales de la baja masa ibera lo solucionaron en el s. V a.C., sirviendo en los ejércitos cartagineses, que operaban en Sicilia contra los griegos y contra los romanos durante la Segunda Guerra Púnica. Los celtíberos eran los mercenarios de los turdetanos (Liv. 34.19), al comienzo de la conquista bárquida del sur, como Istolacius e Indortas (Diod. 25.10), que lucharon contra Amílcar defendiendo a los turdetanos.

Las continuas razzias de celtíberos y lusitanos para solucionar su grave problema económico y social, de las que hablan con frecuencia las fuentes greco-romanas, explican estas destrucciones. Apiano (/b. 56-57), al comienzo de la Guerra Lusitana (155-153 a.C.), menciona las razzias de los lusitanos a las órdenes de Punicos contra los blastofenicios asentados en Turdetania. Muerto Punicos le sucedió Cesaros. Otro caudillo Kaucanos atacó a los cuneos que habitaban el Algarve, desde donde pasaron el estrecho y atacaron Ocilis. En el año 409-408 a.C., las tropas mercenarias cartaginesas, entre las que había muchos iberos, tomaron Himera y destruyeron los santuarios entre los que se encontraba el magnífico templo levantado con ocasión de la paz del 480 a.C...En el año 396 saquearon las tumbas de Gelón, el vencedor de la batalla de Himera del 480 a.C. y de su esposa Damarate. Se destruyó también el santuario de Demeter y Kore. La peste que siguió se interpretó como un castigo de las diosas.

Un texto de Estrabón (III.4.5), muy significativo para conocer las causas de estas razzias que obedecen a las continuas luchas de unas tribus con otras, dice asi: "este mismo orgullo alcanzaba entre los iberos grados mucho más altos, a los que se unía un carácter versátil y complejo. Llevaban una vida de continuas alarmas y asaltos, arriesgándose en golpes de mano, pero no en grandes empresas, y ello por carecer de impulso para aumentar sus fuerzas uniéndose a una confederación potente. Así, pues, si hubieran logrado juntar sus armas, no hubieran logrado dominar la mayor parte de sus tierras, ni los cartagineses, ni antes los tirios, ni los celtas". Estrabón a estas razzias las lleva a tiempos de los cartagineses $y$ de los fenicios.

Un texto de Diodoro (V.34.6), que cita expresamente a Posidonio - quien vino a Cádiz a estudiar el fenómeno de las mareas, y que es fuente fundamental para la Península Ibérica, muy usada por Estrabón (III.1.5; 2.5; $2.9 ; 2.15 ; 3.3-4 ; 4.3 ; 4.13 ; 4.15 ; 4.17 ; 5.5 ; 5.7$; 
10; V.1.14) - es muy claro en la causa de estas razzias: "existe una costumbre muy propia principalmente de los lusitanos, y es que cuando alcanzan la edad adulta, los que están más apurados de recursos, pero sobresalen por el vigor de sus cuerpos y su denuedo, proveyéndose de valor y de armas, se reúnen en las asperezas de los montes. Alli forman bandas numerosas, que recorren Iberia acumulando riquezas con robos, y ello lo hacen con el más completo desprecio de todo". Este texto no admite una interpretación del rito de iniciación del bandolerismo lusitano. Galba, en el año 151150 a.C., atrajo a los lusitanos con la promesa de darles tierras "pues decía que es la esterilidad de vuestros campos y la pobreza la que os obliga al bandidaje, por lo que, si queréis mi amistad, os daré, ya que lo necesitáis, tierras buenas y os estableceré en una fértil campiña, dividiéndolas en tres partes" (App. Ib. 58-60).

La Dama de Elche tampoco es un retrato. No se puede hablar de retrato antes de Lisipo, Zeusis y Pirgoteles (Pollitt, 1989, 49-91; Bieber, $1955,42-57)$ que retrataron a Alejandro Magno (356-323). En Roma no hubo retrato hasta después del año 100 a.C. (Kukahn, 1953, 249).

A partir del s. III a.C. las tumbas en ciertas ciudades de Italia se señalaban con bustos femeninos (Bianchi Bandinelli y Giuliano 1973, 329-333, figs. 379-385) como Palestrina, Pompeya, Capua, Teano y Roma.

\section{ADOLFO DOMÍNGUEZ}

Para A. Domínguez, se trata de una escultura que representa una figura femenina ataviada con un complejo sistema de vestimenta y adorno claramente ibérico; no obstante, ha sido realizada por un escultor que era buen conocedor de las novedades técnicas y estilísticas mediterráneas y, más concretamente, griegas. Ya sea una obra propia de creación o haya sido inspirada en una escultura vestida anterior como sugiere M. Bendala, el escultor está dentro de las tendencias artísticas ibéricas del momento, en las que predomina claramente la estética helenizante.

Todos los objetos que porta la escultura tienen claros ejemplos y paralelos en objetos reales que la Arqueología ha ido revelando en la propia zona geográfica en la que se inserta (el mundo ibérico del sudeste de la Península). El contexto histórico probable de su realización empieza ahora a ser bien conocido merced al papel importante que representa llici como cabeza de la Contestania meridional y sus cada vez más claras relaciones con el ámbito costero, en el que se hallaba, desde mediados del siglo $\mathrm{V}$ a mediados del siglo IV el establecimiento de La Picola, en el que también se percibe una más que evidente influencia griega.

Por todo ello, puede sugerirse que la cronología de la estatua puede situarse entre fines del s. V e inicios del s. IV a. C.

La escultura apareció ocultada intencionalmente en el área de la muralla de llici; ello descartaría su finalidad funeraria. El interés puesto en su ocultación sugiere el gran aprecio que tenía la imagen para la comunidad ilicitana a la que servía. Ello me lleva a sugerir una función religiosa, siendo tal vez una estatua de culto.

La escultura ha sido claramente modificada a lo largo de su historia, y antes de su ocultamiento, que no podemos datar con precisión. Posiblemente fue partida para convertirla en un busto; no sabemos si pudo ser una estatua estante o sedente, pero el corte descuidado y los golpes de herramienta que presenta el actual busto en su parte inferior parecen dejar claro que la estatua original era de mayor tamaño. El agujero que aparece en la parte trasera de la escultura pudo haber sido realizado asimismo en cualquier otro momento, incluso para haber servido como relicario en el que guardar algún objeto ritual o cultual. En todo caso, no parece un espacio lo suficientemente amplio como para haber albergado restos funerarios.

\section{MANUEL BENDALA}

La Dama de Elche, en opinión de este catedrático que ha estudiado bien el mundo ibérico (Bendala 1994, 84-115), es susceptible de muchas formas de aproximación, de análisis, como acredita su extensa historiografía al cabo de más de un siglo transcurrido desde su descubrimiento. Muchos estudios sobre la Dama han discurrido por la vertiente positivista: analizar de qué se trata, un busto de piedra con determinados rasgos formales o estilísticos. Con base en las deducciones obtenidas pueden, sin embargo, ensayarse nuevas hipótesis que la cuestionen a la búsqueda de más respuestas a las muchas interrogantes que plantea y enriquecer nuestra percepción, su valoración arqueológica.

Puede observarse -y sostenerse- que la Dama de Elche condensa, en lo que ahora 
tenemos, una sucesión de fenómenos que la convierten en una realidad más compleja que una simple creación escultórica; y puede contemplársela como algo más que el resultado de una única pulsión creativa: aquella que la concibió y le dio forma. En su compleja y todavía problemática realidad material pueden percibirse diversos momentos o fases, deducibles de un atento análisis de la escultura y de la valoración de sus resultados a la luz de la etnografía o la paleoetnografía, o de la historia de las religiones. Es decir, planteándonos no sólo qué y cómo es, sino el por qué de su aspecto y de sus detalles formales, para qué sirvió, por qué fue transformada si es que lo fue.

A partir de la observación, sobre la que existe acuerdo unánime, del realismo de su tocado y sus complementos, y de referentes ampliamente tratados, pueden desarrollarse hipótesis que pueden resultar altamente operativas para el entendimiento de la Dama. El realismo sorprendente e innecesario de muchos detalles sugieren que la escultura en piedra que vemos copia una figura con joyas y complementos reales, que por bastantes indicios debió de tratarse de una imagen ideal -no de una figura humana- y seguramente una imagen de madera de vestir, una de las manifestaciones más comunes e importantes de la religiosidad mediterránea antigua (con conocida perduración hasta nuestros días). Aparte de los numerosos testimonios disponibles para el mundo griego y romano, específicamente para Hispania se tienen datos de época romana, cuando la información textual y epigráfica se hace abundante, que acreditan la práctica de enjoyar y adornar imágenes de culto como el famoso epígrafe dedicatorio a Isis de Guadix, que debe referirse a un regalo para una imagen de culto que no podría ser sino de madera, una práctica y un culto, por lo demás, que aunque de época romana, remite a tradiciones anteriores bien conocidas y documentadas.

La realización a partir de una imagen de madera, cuya reproducción en piedra podría explicarse como resultado de una veneración especial u otras razones fácilmente argumentables, explicaría la conformación de la imagen, la inorgánica estructura de los hombros, la carencia de senos, una apariencia, en fin, propiciada por el hecho de consistir originariamente, como era y es frecuente en las imágenes de vestir, en una figura casi informe, apenas un tronco o un maniquí sin detalles anatómicos, en el que sólo se tallaban con detalle la cabeza y, acaso, las manos y los pies, si era una figura completa.

La escultura originaria, por razones estilísticas y, en general, arqueológicas, pudo realizarse en el siglo $V$ a.C., y copiarse en piedra en un momento posterior, hacia el siglo III a.C., contemporáneo seguramente al de esculturas como la Gran Dama del Cerro de los Santos. Ésto último puede argumentarse con algún fundamento, entre otras cosas, por la forma en que está tratado el ropaje de la Dama de Elche, con pliegues laterales idénticos a los de la del Cerro, o por idéntica concepción en el plegado, muy geométrico, del borde o solapa del manto.

Parece también evidente -por el abrupto corte de la base, en lo físico y en lo compositivoque el busto procede de una escultura completa, seguramente sedente, por la forma característica del perfil anterior del busto, que se acerca al propio de esculturas como la Dama de Baza y se aleja de la disposición que presentan las estantes, como la misma Gran Dama del Cerro. Debieron de ser razones de índole y significación religiosas las que explican la transformación en busto; como se ha propuesto, tal vez por el propósito de obtener una figura asociable a la idea de un ánodos -el ser que emerge del suelo de la tierra-, algo que pudo darse cuando triunfaron ese tipo de iconografías en las cerámicas ilicitanas de fechas recientes, ya bajo el dominio romano.

La Dama, por tanto, en lo que ahora se conserva, sería el resultado de al menos tres momentos o fases que la explican: el modelo originario de madera, la copia posterior en piedra y la conversión en busto, para todo lo cual pueden proponerse argumentos con base arqueológica y proyección en el campo de la etnografía y de la historia de las religiones y de las mentalidades antiguas.

\section{MICHAEL BLECH}

Este hispanista del Instituto Arqueológico Alemán de Madrid, buen conocedor de la cultura ibérica (Blech, 2001, 630, lám. 230-231), pone en relación la Dama de Elche con la Dama de Cabezo Lucero, y ambas con la Dama de Baza, que son urnas de cenizas. Se inclina a creer que, en origen, era una figura de pie o entronizada. Tampoco sabe si era una diosa o una mortal y su verdadera función, si era una 


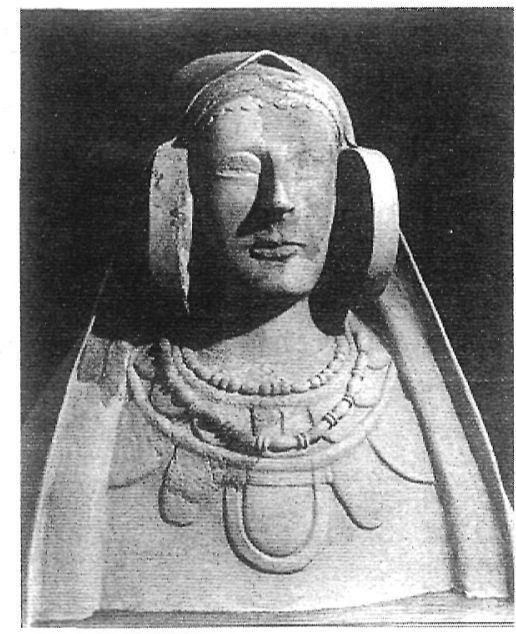

Figura 28: Dama de Cabezo Lucero. Foto E. Llobregat.

urna o una estatua usada después para una función nueva.

\section{JOSÉ UROZ}

El catedrático de Historia Antigua de la Universidad de Alicante, excavador y buen conocedor del mundo ibérico, ha tenido la gentileza de enviarme la bibliografía fundamental sobre la Dama de Cabezo Lucero (Fig. 28), que es el paralelo más próximo para la Dama de Elche. Se trata de un busto femenino aparecido en la necrópolis de Cabezo Lucero, en posición frontal y en reposo. Los fragmentos recogidos excluyen que se trate de una figura de pie; la reconstrucción es segura. La Dama cubre la cabeza y los hombros con un mantón, lleva la peineta del mismo modo que la Dama de Elche, en lo alto de la cabeza, cubierta por el manto. El pelo está recogido en dos grandes rodetes colocados a ambos lados de la cabeza. Los rodetes son calados como en las citadas damas. Viste túnica y del cuello cuelgan cuatro collares, dos de ellos compuestos por bulas de forma de lengüeta, colgadas de asas metálicas. El superior está formado por siete bulas de lengüeta. Debajo de este collar hay un segundo, también con bulas parecidas a las anteriores, de mayor tamaño.

Sobre estos collares se colocaron dos gargantillas o sartas, formadas de cuentas de pasta vítrea. Las sartas de collar superpuestas están compuestas por cuentas de forma de huesos de olivas, esféricas y planas o discoidales, de acuerdo con el siguiente esquema: huesos de oliva, esférica, plana, esférica y hueso de oliva. Más abajo hay otra sarta de collar compuesta por cuentas más gruesas ordenadas siguiendo dos cuentas discoidales y una de tonelete.

La Dama de Cabezo Lucero se ha fechado, dentro del primer tercio, o cuarto, del s. IV a.C., anterior a la Dama de Elche que es un busto elaborado y barroquizante (Llobregat y Jodin, 1990, 109-122).

Sartas en formas de huesos de oliva se encuentran en el collar de La Aliseda, fechado en torno al 600 a.C. (Nicolini, 1990, 436-441, lám 122-123d, 124d, 125, 126, 127d), en un collar de Cádiz (Nicolini, 1990, 442-443, lám. 128) y en otro de Huelva (Nicolini, 1990, 444445, lám. 129a). En este último collar las cuentas son esferas. Se data esta pieza en el último cuarto del s. VII a.C., al igual que un collar procedente de Andalucía, hoy conservado en el MAN (Nicolini, 1990, 450-452, lám. 137ab). Este tipo de joyas están documentadas en Etruria. Así, las esferas en collares de la Tumba del Littore, en Vetulonia, en torno al 630 a.C. (Cristofani y Martelli, 1983, 115, 271). Las esferas y los huesos de olivas se encuentran en collares de Palestrina, en la primera mitad del s. VII a.C. (Cristofani y Martelli, 1983, 277, fig. 87, de mayor tamaño); de Narce, en torno al 650 a.C. (Cristofani y Martelli, 1983, 132133, 278-279); de Tarquinia, s. IV a.C., con esferas; de Pescia Romana, de la segunda mitad del s. IV a.C., también con esferas (Cristofani y Martelli, 1983, 236-237, 315, figs. 268).

En Grecia también se documenta este tipo de joyas, como en Eleusis, con esferas, s. VIII a.C. (Musti, 1992, 101, 242, fig. 48), al igual que en un ejemplar del British Museum (Musti, 1992, 144, 247, fig. 67) y de Polis-tis-Chrysokou, primera mitad del s. V a.C. (Musti, 1992, 115, 258, fig. 145), etc. De Cartago, s. VII-VI a.C., se conoce algún collar formado de cuentas de esferas (Pisaro, 1988, 377), cuentas que se repiten en el Cortijo de Évora (Pisaro, 1988, 392), s. VII a.C.

Por todo el Mediterráneo circuló una koine artística de joyas que se copiaban en diferentes ciudades.

\section{RICARDO OLMOS}

Este investigador de C.S.I.C., que ha estudiado a fondo la cultura ibérica, cree que la Dama de Elche es una escultura funeraria y que estaba de pie. 
Conocemos la Dama de Elche como busto, y como tal pudo haber mantenido vivo un sentido cultural en la Antigüedad. Las indicaciones de su descubrimiento en el s. XIX sitúan a la Dama junto a las murallas de $/ / i c i$. Esto puede indicar un proceso secundario en la misma antigüedad. Con anterioridad cabe suponer que la Dama ha podido pertenecer a una necrópolis donde recibiria, en el orificio de su espalda, las cenizas de un personaje principal como hoy suponemos también para el Varón o "Guerrero" de Baza. Situaríamos ese primer momento de la Dama probablemente en la segunda mitad del s. V a.C. Retallada, su busto mantiene el sentido de memoria originaria, como en tantas otras piezas y pasa a revestirse del sentido heroico de una reliquia. Enterrada y protegida en esta nueva situación puede proteger la muralla, la ciudad.

Hay que considerar a la Dama, figura llena de pregnancia, dentro de la memoria histórica, anterior, que muestra tan frecuentemente el mundo ibérico. La Dama de Galera, Porcuna, timiaterio de la Quéjola, etc. Ya se ha indicado que la Dama de Cabezo Lucero puede ser un indicio de ese recuerdo y emulación de la Dama de Elche en esta necrópolis próxima de Alicante. La época iberohelenística pudo recuperar y reutilizar políticamente esa memoria prestigiosa, como ocurre en otros ejemplos.

Desde el punto de vista escultórico, la Dama está llena de detalles singulares como las buscadas asimetrias en la disposición de vestidos y joyas y en el mismo rostro, que son rasgos intencionales del artista: las ligeras variaciones expresan que es una figura viva. Estos matices son propios de las esculturas de época temprana como la misma Dama de Baza.

\section{LORENZO ABAD}

Su opinión sobre la Dama de Elche es de gran valor por dedicarse a estudiar la cultura ibérica. A continuación transcribimos parte de un trabajo inédito que amablemente nos ha hecho llegar, que corresponde al texto escrito de una conferencia pronunciada en un seminario sobre el centenario de la Dama, en Elche, en el año 1996. El título es La dama de Elche en su contexto mediterráneo, y tenía como intención principal hacer una llamada de atención acerca de que la Dama es ante todo una escultura y por tanto una obra susceptible de estudio iconográfico y estilístico para relacionarla con las corrientes culturales artísticas, técnicas e iconográficas del momento en que se realizó. Algo muy próximo, por tanto, a lo que hemos desarrollado a lo largo de este estudio.

\section{La Dama de Elche en su contexto inmediato}

La Dama de Elche fue en su momento un hallazgo aislado, algo excepcional en un yacimiento que habia proporcionado materiales de muy diverso tipo, pero ninguna pieza similar. Con el paso del tiempo fueron apareciendo otras esculturas que permitieron arroparla, y especialmente los numerosos fragmentos de piezas similares que Ramos Folqués encontró reutilizados en el pavimento de una calle del siglo III aC. Este conjunto se ha puesto en relación con el edificio excavado hace algunos años por Rafael Ramos y Enrique Llobregat, que se ha identificado con un templo, pero del que persisten algunas dificultades de interpretación (Ramos Fernández, 1995, 115). En primer lugar, su fecha; lo único seguro es que estas piezas están reutilizadas en un contexto del siglo III, pero poco se sabe acerca del momento de su destrucción; y menos aún del de su fabricación, ya que la más significativa es un capitel protojónico que apareció formando parte de un muro de la basilica construida siglos después sobre los restos de este edificio. Lo que parece es que, dada la fecha ante quem de su reutilización, el origen de la Dama y de las demás piezas se encuentra en los siglos $\mathrm{V}$ IV aC.

Si la Dama perteneciera a este conjunto, lo que parece probable, sería una de las pocas obras de este tipo procedente de un recinto sacro, ya que la mayoría son o bien de tumbas, caso de la Dama de Baza, o bien de santuarios, como las numerosas figuras del Cerro de los Santos. Tampoco sabemos a quién representaria, aunque parece evidente que no se trata de un retrato propiamente dicho, pues en ese momento esta idea, tal y como la entendieron los romanos y la entendemos aún hoy, no estaba desarrollada en el Mediterráneo; y si las piezas hay que estudiarlas en el contexto en el que se enmarcaron, difícilmente se puede suponer una ruptura tan fuerte como para inventar el retrato en una obra perdida de Iberia, por muy buena que fuera. En todo ello volvemos a encontrar, una vez más, problemas de estilo.

\section{La Dama de Elche en su contexto próximo}

La Dama de Elche, un busto con adornos especificos y poco frecuentes, que procede de 
un recinto religioso en un marco urbano, sólo puede compararse, por su carácter de pieza única, con esculturas ibéricas de distinto tipo y función, lo que conlleva necesariamente un proceso de descontextualización que sin duda alterará los resultados que puedan conseguirse. A partir de este dato, hay que adoptar una serie de estrategias que faciliten la obtención de conclusiones.

Una de ellas es la posible comparación con otros rostros femeninos de la cultura ibérica que se daten grosso modo en este momento, de los que existen pocos ejemplares. Michael Blech y Encarnación Ruano han puesto en valor recientemente la cabeza de una esfinge que procede de Úbeda la Vieja, en la provincia de Jaén (Blech y Ruano, 1992, 70-101; 1993, 2744), comparable con piezas ya conocidas como la de Alicante hoy en Barcelona, las de la necrópolis del Llano de la Consolación y otras femeninas, encuadrables todas ellas hacia mediados del siglo $\mathrm{V}$ aC. Son piezas de rostro oval, ojos almendrados de disposición horizontal u oblicua, en ocasiones con los párpados finamente realzados. Algunos de estos rasgos -realizados con diferente grado de dominio técnico y acabado-pueden verse también en cabezas masculinas de este período y en concreto en las del guerrero número 1 de Porcuna y del caballero de Los Villares, datados en diferentes momentos a lo largo del siglo $\mathrm{V}$ $a C$.

Con varios de ellos admite la Dama de Elche una comparación estilística y, aunque no sea éste el lugar de analizarlos en pormenor, ya que los detalles pueden encontrarse en el artículo de Blech y Ruano citado más arriba, interesa destacar por el momento que los rasgos iconográficos generales de la Dama se adscriben al acervo común de lo ibérico. Da lo mismo que se trate de figuras masculinas o femeninas porque, como ocurría en el arte griego y en no pocas artes más, la pertenencia a un estilo común une mucho más de lo que separan las diferencias de tiempo y de lugar.

Si tomamos como elemento de referencia una escultura de mediados del siglo $\mathrm{VaC}$, como es el llamado 'Guerrero número 1' de Porcuna, vemos que en él se reproducen algunos de los rasgos de la propia Dama: epidermis muy lisa, que contrasta con lo acentuado y bien perfilado de los rasgos faciales: nariz recta, fina y larga, que enlaza directamente, aunque con una marcada inflexión, con los arcos superciliares; ojos entreabiertos y ligeramente abultados, de párpados firmes y bien perfilados, con el iris marcado en un caso (guerrero) y ahuecado en otro (dama); labios finos que no llegan a unirse en las comisuras. Todo ello es lo que confiere el aire 'arcaico' característico a estas figuras. Son rasgos iconográficos similares que comparten dos piezas -entre otras varias- de cronología similar pero separadas por cuatrocientos kilómetros, aunque cada una de ellas presente una expresión propia: melancolía y 'tristeza' en la dama, firmeza en el guerrero. Son imágenes tipológicas, que reproducen un 'tipo' determinado, con rasgos más o menos personalizados: el guerrero y la figura divina respectivamente. Estamos, una vez más, ante cuestiones de estilo, que hay que enmarcar dentro de los contextos ideológicos e iconográficos en los que nuestra Dama se originó.

\section{La Dama de Elche en su contexto me- diterráneo}

La escultura ibérica no es algo que surja por generación espontánea, sino que lo hace inserta en el contexto cultural del Mediterráneo en un momento determinado, que permite que un grupo no demasiado amplio de culturas produzcan escultura monumental. La simple búsqueda de paralelos con los que comparar nuestra figura, que podría resultar muy lucida desde muchos puntos de vista, no dejaría de ser algo estéril. Será necesario centrar la atención en aquellos aspectos que más determinantes podrian ser para el encuadramiento estilístico y temporal de la Dama.

Para ello es de interés partir de la noción de estilo, definida por el Diccionario de la Real Academia Española como "carácter propio que da a sus obras el artista, por virtud de sus facultades". Pero creo que el estilo artístico es algo más: un conjunto de rasgos observables en los que se reflejan los principios conceptuales de una época histórica y el dominio técnico de unos artesanos que le dan forma visible. Ambos principios son fundamentales y están intimamente relacionados; sin fundamentos conceptuales no hay estilo ni arte, $y$ sin dominio técnico no hay forma posible de expresarlos. Así lo vio Winckelmann en su sistematización de la escultura griega -siempre es útil recurrir a las fuentes originales- $y$ asi lo han visto todos cuantos a lo largo del tiempo han definido los diversos estilos, comenzando por la propia definición de los estilos severo y clásico en la escultura griega (Ridgway, 1970; 1977).

Problema importante y debatido es el de si puede hablarse de uno o de varios estilos 
ibéricos, algo que no resulta fácil, ya que el número de piezas conservadas no es 10 suficientemente amplio como para poder contrastar las observaciones realizadas en unos pocos casos con otros ejemplares ibéricos y con los demás estilos y monumentos del Mediterráneo.

La tipologia estilistica que de las obras ibéricas podamos realizar se encuentra con el problema de que en no pocas ocasiones se trata de una serie de obras únicas, cuya interrelación formal es débil y en las que sólo pueden rastrearse atisbos, reminiscencias, recuerdos de relaciones mediterráneas que pudieron haber influido en su origen y desarrollo. Desde casi el primer momento se pensó que estas relaciones formales de las esculturas ibéricas con determinados modelos griegos, sobre todo del sur de Italia, tenían algo que ver con la aparición de la propia escultura ibérica, y aunque con el paso del tiempo esta dependencia originaria haya sido minusvalorada en favor de otras posibilidades, la realidad es que en el fondo las diferentes posiciones, salvo en posturas muy radicales, no se revelan excluyentes sino complementarias.

\section{Bases iconográficas de la Dama de Elche}

El arte ibérico debe ser considerado por tanto como un arte mediterráneo, que se relaciona con otras artes mediterráneas en temas y en rasgos técnicos y estilísticos. Pero en el entorno de este mar no hubo un solo modelo expresivo cultural ni cronológico, sino varios, aunque todos ellos tuvieran en determinado momento de su historia el arte griego como punto de referencia. El ibérico se relacionó con varios de ellos, aunque la importancia otorgada a la intensidad y el momento de estas relaciones ha oscilado a 10 largo de la historia en función de los autores que se ocuparon del tema; lo tradicional ha sido relacionarla con lo griego focense, y esta es la opinión de buena parte de los investigadores de mayor prestigio (Carpenter, García y Bellido, Langlotz, Tarradell, Blanco, Blázquez, Negueruela, Nicolini; cf. Bendala, 1994, 85 sigs.; León, 1997, 66 sigs.; Olmos y Tortosa, 1997). Otros autores pusieron por delante de cualquier otra consideración la originalidad y la autoctonia, el orientalismo, los modelos pequeños; es la hipótesis 'antigrequizante', que encabezó en su momento Enrique Llobregat: la escultura ibérica era una invención propiamente ibérica, $y$ en todo caso sus modelos más inmediatos serían originales pequeños, piezas fácilmente transportables que constituyeron los originales sobre los que trabajó el artesano ibero (Abad, 2000, 40-43). Esta postura, que podriamos calificar de extrema, ha sido valorada nuevamente, aunque con considerables matizaciones por autores como Pilar León, para quien las semejanzas entre el arte ibérico y el griego, más que de fondo son accidentales, aparentes, externas (León, 1997).

Hoy en día, la hipótesis más aceptada -y a la que desde luego me sumo-es la de que en el origen del arte ibérico se encuentran diversas influencias mediterráneas, aunque la concreción del papel y el significado de cada una de ellas no esté tan claro. Tengo para mí -y no soy desde luego el único-que en este origen se encuentra una doble influencia; la del mundo que denominamos orientalizante y la de componente griego. Ambas se suceden en un corto espacio de tiempo, con diferente intensidad en según qué lugares, pero es el fuerte impacto de lo helénico sobre una base ya previamente cultivada lo que va a dar lugar al arte escultórico ibérico.

El primero, que por el momento parece algo más antiguo, está representado principalmente en Pozomoro, en tanto que el segundo, helenizante, es visible -a través de diversos filtros técnicos y conceptuales- en la mayoría de los demás monumentos y ante todo en los de Elche y Porcuna. Es esa confluencia de modelos orientalizantes y griegos la que dará origen a la escultura en la Península Ibérica, ya que con anterioridad apenas existió obra que pudiese llevar ese nombre. Este proceso se produce -y en esto tiene razón Pilar León- en torno a un conjunto de obras, escultores $y$ modelos que en comparación con otros lugares del Mediterráneo -y de aplicar sus cánones artísticos- habria que considerar como de segunda o tercera fila, dentro de un marco de contactos mucho más amplios con el Oriente, Grecia y el sur de Italia y en un momento en que en estos territorios el estilo artístico abandona los conceptos y rasgos del Arcaísmo para formar los del Estilo Severo. Cristaliza en un arte local ingenuo y repetitivo, anclado en un ideal arcaico, que unifica las dos grandes corrientes que se encuentran en los orígenes del arte ibérico: los elementos griegos, míticos, del Levante, y los orientales de Pozo Moro, que encarnan una forma diferente de representación mitológica y religiosa.

La escultura era entonces patrimonio de unos pocos grupos conservadores que exal- 
taban sus principios: los animales -fantásticos en una primera etapa- eran seres miticos y figuras simbólicas detentadoras de fuerzas sobrenaturales; la figura humana y los combates simbolizaban la divinidad y el poder y se representaban de una manera descriptiva, exuberante, con gran simplicidad de formas pero intensa riqueza ornamental.

La subsiguiente ruptura en el ambiente cultural mediterráneo hizo que el arte ibérico siguiera su propio camino, con muy pocas concomitancias con lo que fue el griego posterior, y que cristalizaran como clásicos unos códigos artísticos que en comparación con los de otras culturas mediterráneas seguian anclados en los conceptos que convencionalmente identificamos con el 'arcaísmo'. Lo clásico -"el autor o la obra que se tiene por modelo de imitación en cualquier literatura o arte", según el Diccionario de la Real Academia Española- es para el mundo ibérico repetición estereotipada de figuras con rasgos antiguos como ojos prominentes, boca rigida y rictus que recuerda los últimos epígonos de la llamada 'sonrisa arcaica'; elementos del rostro muy bien perfilados, rígidos paños superpuestos con pliegues rectos que caen en zigzag, etc.

La escultura levantina y en concreto la Dama de Elche muestra muchos de estos rasgos ibéricos 'clásicos': ojos rasgados, cejas arqueadas, proporciones similares a las del arte grecooriental de finales del arcaísmo e inicios del clasicismo; ello encuentra no pocas concomitancias con obras mediterráneas de ambiente griego de esta misma época. Se han superado los rígidos conceptos del arcaísmo, los ojos almendrados y saltones, la boca rígidamente dibujada, los labios que no se tocan en las comisuras, y nuestra figura se encuentra mucho más estrechamente relacionada con originales griegos del clasicismo inicial, datadas en el segundo cuarto del siglo $\mathrm{V}$ aC. En nuestra intervención colacionamos, entre otras, el Efebo Rubio, la Atenea del frontón oriental del templo de Egina, el Apolo de Zeus en Olimpia, la diosa tal vez Hera- del templo E de Selinunte, la diosa de Tarento, la Hera de la metopa de Zeus y Hera en Selinunte, y cómo no, el propio Auriga de Delfos. Muchas de ellas coinciden con las que poco tiempo después pudimos ver recopiladas en el trabajo de G. Nicolini (Nicolini, 1997, 107-124), publicado por aquellos mismos días aunque llegado a nuestras manos con un cierto retraso. Este autor incorpora a la relación algunas otras figuras que abundan en la misma dirección y resultan también de gran interés: el Apolo
Chatsworth, quizás la figura que más veces ha sido comparada con la Dama, y una Cabeza del Vaticano, posiblemente de la Magna Grecia, con los ojos incrustados al igual que la Dama.

Esta -a la que se podrían añadir otras muchas a lo largo de los años - es ilustrativa, a nuestro juicio, de que la Dama de Elche, en cuanto a la iconografía de su rostro, presenta fuertes relaciones con obras griegas del segundo tercio del siglo $\mathrm{VaC}$, relaciones que se adivinan demasiado intensas como para ser fruto de la casualidad y similitudes que pueden hacerse extensivas también a obras de otros ambientes mediterráneos, sobre todo del mundo etrusco.

Todo ello hay que encuadrarlo en el fenómeno cultural conocido como 'estilo severo', una forma de representación artística que se extiende por todo el Mediterráneo y al que hay que referir también buena parte de las esculturas ibéricas del momento. Podría ser, claro es, que estos rasgos de la Dama de Elche no fueran consecuencia de una relación temporal inmediata sino pervivencia de rasgos anteriores (Bendala, 1994, 85 ss), algo que en cualquier caso seria ahora secundario para el fin que nos proponemos: recordar que las esculturas deben ser estudiadas desde un punto de vista estilístico, el único que permite realizar propuestas de inserción en un contexto cultural y -por extensión geográfico y cronológicocuando faltan argumentos teóricamente más sólidos desde el punto de vista arqueológico.

Creo no obstante y a diferencia de no pocos colegas, que la cronología de la Dama de Elche encaja mejor en el siglo $V$ que en el $I V$, toda vez que algunas de las figuras más próximas estilisticamente se encuentran datadas por criterios arqueológicos dignos de confianza en una fecha que, grosso modo, se encuentra dentro de este período temporal, en tanto que las más alejadas -ejemplos de la Dama de Baza o de las del Cerro de los Santosresponden a conceptos iconográficos distintos.

Hemos realizado, en suma, una breve excursión por algunos aspectos del arte ibérico, proponiendo el estudio de sus piezas escultóricas en un triple contexto: el del conjunto arqueológico donde aparecieron, el del entorno inmediato en que se insertan y el más amplio de las relaciones mediterráneas sin las que difícilmente habrian podido surgir. A partir de todo ello hemos podido observar cómo la escultura ibérica en general, y la Dama de Elche en particular, son testimonio de un arte singular, relacionado con otras artes mediterráneas y 
especialmente con la evolución escultórica del mundo griego, aunque mostrando una personalidad propia que las independiza de cualquier origen concreto y les proporciona un código expresivo propio y peculiar. Muchas de estas piezas son piezas únicas y tal es también la Dama de Elche, la amplitud de cuya fama le viene quizás por ser la menos ibérica de todas las obras ibéricas.

\section{CONCLUSIÓN}

Este trabajo sólo ha pretendido recoger algunos testimonios de la historiografía de la Dama de Elche, que en los últimos años se ha estudiado en profunidad (Olmos y Tortosa 1997; AA.VV. 1996). Algunas opiniones, como las de Jacobsthal, Langlotz, Kukahn, Schubart, Blanco, están hoy un tanto olvidadas, pero siguen siendo fundamentales; a ellas se han añadido las de algunos de los grandes especialistas actuales en la cultura ibérica.

Podemos decir que, recogiendo el espíritu de la mayoría de las opiniones, hay una tendencia a remontar la cronología del busto al s. V a.C. Varios arqueólogos la consideran de carácter funerario, otros la tienen por una diosa y todos señalan en ella un influjo del arte griego.

Prof. José María Blázquez

Real Academia de la Historia

c/León 21

28014 Madrid

\section{BIBLIOGRAFÍA}

AA.VV., 1996: La Dama de Elche más allá del enigma, Valencia.

AA.VV., 1999: Santuarios fenicio-púnicos en Iberia y su influencia en los cultos indígenas, ibiza.

ALMAGRO GORBEA, M.J., 1980: Corpus de las terracotas de Ibiza, 128-129, lám. LXVIII-LXIX, Madrid.

ALMAGRO GORBEA, M.J., 1980: Corpus de las terracotas de Ibiza, 198-199, lám. CXXXI, Madrid.

ALMAGRO GORBEA, M.J., 1994: Historia de España. Desde la prehistoria hasta la conquista romana (siglo III a.C.), 244-245, Barcelona.

ABAD CASAL, L., 2000: "Enrique A. Llobregat: treinta años de arqueología alicantina", en Homenaje a Enrique $A$. Llobregat Conesa, 39-53, Alicante.

AUBET, M.E., 1858: "Algunos aspectos sobre iconografía púnica: las representaciones aladas de Tanit", Homenaje a Garcia y Bellido 1, 61-82, Madrid.

BECATTI, G., 1965: L'Età clasic, a244-245, Florencia

BENDALA, M. 1996: "Reflexiones sobre la Dama de Elche", REIG १, 85-105.

BIANCHI BANDINELLI, R. y GIULIANO, A., 1973: Los etruscos y la ltalia anterior a Roma, Madrid.
BIANCHI BANDINELL!, R. y GIULIANO, A., 1973: Los etruscos y la Italia anterior a Roma, 165-166, Madrid.

BIANCHI BANDINELLI, R. y GIULIANO, A., 1973: Los etruscos y la ltalia anterior a Roma, 193, fig. 225, Madrid.

BIANCHI BANDINELLI, R. y GIULIANO, A., 1973: Los etruscos y la Italia anterior a Roma, 229-233. figs. 379385, Madrid.

BIEBER, M., 1955: The Sculpture of the Hellenistic Age, 4257 , Nueva York.

BLANCO, A., 1957: Museo del Prado. Catalogo de la escultura I. Escultura clásica II. Esculturas, copias e imitaciones de las antiguas, 130-133, láms. LXXVIILXXVIII, Madrid.

BLANCO, A., 1981: Historia del arte hispánico I. 2. La Antigüedad, 47-50, Madrid.

BLANCO, A., 1996: Antonio Blanco Freijeiro. Opera Minora en J.M. Luzón y P. León (eds.), 533-613, Sevilla.

BLÁZQUEZ, J.M., 1988: Historia del Arte Hispánico. I. La Antigüedad 1, 221-222, Madrid.

BLÁZQUEZ, J.M., 1992: Fenicios, griegos y cartagineses en Occidente, 387-421, Madrid.

BLÁZQUEZ, J.M., 1999: Mitos, dioses y héroes en el Mediterráneo antiguo. Madrid. 175-319.

BLÁZQUEZ, J.M., 1999: Mitos, dioses y héroes en el Mediterráneo antiguo, 341-362, Madrid.

BLÁZQUEZ, J.M., 1999: "Temas religiosos de la pintura vascular tartésica e ibera y sus prototipos del Próximo Oriente fenicio", Lucentum, 93-116.

BLÁZQUEZ, J.M., 2000: Los pueblos de España y el Mediterráneo en la Antigüedad, 94-103, Madrid.

BLÁZQUEZ, J.M., 2000: Los pueblos de España y el Mediterráneo en la Antigüedad, 287-318, Madrid.

BLÁZQUEZ, J.M., 2001: Religiones, ritos y creencias funerarias de la Hispania Prerromana, 315-323, Madrid.

BLÁZQUEZ, J.M., 2003: El mediterráneo y España en la Antigüedad, 324-404, Madrid.

BLECH, M., 2001: Denkmäler der Frühzeit. Hispania Antiqua, 622-623, láms. 221-223, Maguncia.

BLECH, M., 2001: Denkmäler der Frühzeit. Hispania Antiqua, 626-628, láms. 225-226, Maguncia.

BLECH, M., 2001: Denkmäler der Frühzeit. Hispania Antiqua, 630, láms. 230-231, Maguncia.

BLECH, M. y RUANO, M., 1992: "Zwei iberische Skulpturen aus Úbeda la Vieja (Jaén)", MM, 33, 70-101.

BLECH, M. y RUANO, M., 1993: "Dos esculturas ibéricas procedentes de úbeda la Vieja, Jaén", Boletín de la Asociación Española de Amigos de la Arqueologia, 33 , 27-44.

BOSH-GIMPERA, P., 1961: "Arte Ibérica", EAA, IV, 73

CARO BAROJA, J., 1971: "La realeza y los reyes en la España Antigua", Estudios sobre la España Antigua, 99159, Madrid.

CATENI, G., FLASCH, F., 1984: Le urne di Volterra e l'artigianato artistico degli etruschi, Láms. IV, 16, Florencia.

CRISTOFANI, M., 1985: I bronzi degli etruschi, Novara.

CRISTOFANI, M., 1985: I bronzi degli etruschi, 73-270, Novara.

CRISTOFANI, M., y MARTELLI, M., 1993: L'oro degli etruschi, Novara.

CRISTOFANI, M., y MARTELLI, M., 1993: L'oro degli etruschi, 305, fig. 311; 307-308, fig. 221-222; 315, fig. 260-261, Novara.

DE MIRO, E., 1996: "Greek Sculpture in Sicily in the Classical Period", en G. Pugliese Carratelli (ed.): The Greek World Art and Civilisation in Magna Grecia and Sicily, 413419, Nueva York. 
FERRER, E. (ed.), 2002: Ex Oriente /ux. Las religiones orientales en la Penísula Ibérica, Sevilla.

FREYER-SCHAUENBURG, G., 1974: Samos XI. Bildwerke der archaischen Zeit und des strenegn Stils, Bonn.

GARCÍA Y BELLIDO, A., 1943: La Dama de Elche, Madrid.

GARCÍA Y BELLIDO, A., 1958: "La Dama de Elche, una creación de época Augustea?”, ArchCl, V, 129-132, láms. XLV-XLVI.

GARCIA Y BELLIDO, A., 1963: Historia de España 1.3. España primitiva. La Hispania Prerromana, 559-574, figs. 481-493, Madrid.

GONZÁLEZ NAVARRETE, J.A., 1987: Escultura ibérica del Cerrillo Blanco. (Pocuna, Jaén), Jaén.

JACOBSTHAL, P., 1932: "Zum Kopfschmuck des Frauenkopfes von Elche", $A M, 457,67-75$.

JANTSEN, V., 1975: "Agyptische und orientalische Bronzen aus dem Heraion von Samos", Samos, VIII, Bonn.

JIMÉNEZ, J., 2002: La toréutica orientalizante en la Península Ibérica, Madrid, passim.

KARAGEORGHIS, S.V., 1982: Cyprus from the Stone Age to the Romans, 142, fig. 108, Londres.

KUKAHN, E., 1953: "Sobre los origenes del retrato romano", AEArq, XXVI, 249.

KUKAHN, E., 1957: "Busto femenino de terracota de origen rodio en el ajuar de una tumba ibicenca", AespA, 30, 3-14.

KUKAHN, E., 1967: Die Griechen und ihre Nachbarn, lám. 373, Berlín.

LANGLOTZ, E., 1951: "Ein Artemis-Kopf", Studies presented to D.M. Robinson on his seventh Birthday, 656, San Luis.

LANGLOTZ, E., 1963: Die Kunst der Westgriechen in Sizilien und Unteritalien, 80-83, láms. 100-113, Munich.

LANGLOTZ, E., 1966: Die kulturelle und künustherische Hellenisierung del Küsten des Mittelmeers durch dier Stadt Phokaia., 60, Colonia, Opladen.

LEÓN, P., 1997: Les ibères, Barcelona.

LEÓN, P., 1998: "La escultura", en C. Aranegui (coord.): Los iberos principes de Occidente, 158-160, Barcelona.

LLOBREGAT, E. y JODIN, A., 1990: "La Dama del Cabezo Lucero (Guardamar del Segura, Alicante)", Saguntum, 23, 109-122.

MARCONI, C., 1994: Selinunte. Le metope. L'Heraion, Modena.

MARIN CEBALLOS, M.C., 2000-2001: "La representación de los dioses en el Mundo Ibérico", Lucentum, XIX-XX, 183-196.

MARTÍNEZ SANTAOLALLA, J., 1996: Esquema paleoetnológico de la Península Hispánica, Madrid.

MOFFIT, F., 1999: Art Forgery. The Case of the Lady of Elche, Florida.

RUIZ BREMÓN, M., 1989: Los exvotos del santuario ibérico del Cerro de los Santos, Albacete.

MORENO, P., 1998: I bronci di Riace. II maestro di Olimpiae i sette a Tebe, Milán

MUSTI, D. ET ALII, 1992: L'oro dei Greci, 101, 242, fig. 48, Novara.

MUSTI, D. ET ALII, 1992: L'oro dei Greci, 114, 247, fig. 67, Novara.

MUSTI, D. ET ALII, 1992: L'oro dei Greci, 145, 258, fig. 145, Novara.

MUSTI, D. ET ALII, 1992: L'oro dei Greci, 253, fig. 96.6; 258, fig. $116 ; 278$, fig. 140.6, Novara.

NICOLINI, D., 1973: L'art et la civilisation de l'Espagne antique. Les ibères, PI. III: d. Paris.

NICOLINI, G., 1990: Tecniques des arts antiques. La bijouterie iberique du VIle. Au IVe siecle, 132-133, 273-279, figs. 132-133, Paris.

NICOLINI, G., 1990: Tecniques des arts antiques. La bijou- terie iberique du VIle. Au IVe siecle, 436-445, láms. 122129 , Paris.

NICOLINI, G., 1990: Tecniques des arts antiques. La bijouterie iberique du VIle. Au IVe siecle, 450-453, Paris.

NICOLINI, G., 1997: "La Dama de Elche: historiografía y autenticidad", en R. Olmos y T. Tortosa (eds.): La Dama de Elche. Lecturas desde la diversidad, 107-124, Madrid.

NICOLINI, G., 1999: Les ibères. Art et Civilization, 84-86, Paris.

NIEMAYER, H.G., 2001: Denkmäler der Frühzeit. Hispania Antiqua, 600, lám. 184a-b, Maguncia.

OLMOS, R. y TORTOSA, T. (eds.), 1997: La Dama de Elche. Lecturas desde la diversidad, Madrid.

PAPAIOANNOU, K., 1972: Griechische Kunst, 524-526, figs. 297-303, Friburgo.

PISARO, G., 1988: "I gioielli", en S. Moscati: / Fenici, 377, 392, Milán.

POLLITT, J.J., 1989: El arte helenistico, 49-91, Madrid.

PUGLIESE CARRATELLI, G. y ARIAS, P.E., 1990: "La Scultura", en G. Pugliese Carratelli, Magna Grecia. Arte y artigianato, 299-305, figs. 352-462, Milán.

RAMOS FERNÁNDEZ, R., 1988: "La escultura antropomorfa de Elche", Escultura Ibérica. Revista Arqueología, 96-97.

RAMOS FERNÁNDEZ, R., 1995: El templo ibérico de La Alcudia. La Dama de Elche, 123-133, Elche.

RAMOS FERNÁNDEZ, R., 1997: La Dama de Elche, Valencia.

RAMOS FERNÁNDEZ, R., 1995: El templo ibérico de La Alcudia, Elche.

RAMOS FOLQUÉS, R., 1945: "La Dama de Elche. Nuevas aportaciones", AEArq, 18, 252-260.

RICHTER, G.M.A., 1968: Korai. Archaic Greek Maidens, Londres.

RICHTER, G.M.A., 1970: Kouroi. Archaic Greek Youths, Londres.

RIDGWAY, B.S., 1970: The Severe Style in Greek Sculpture, Princeton.

RIDGWAY, B.S., 1977: The Archaic Style in Greek Sculpture, Princeton.

ROBERTSON, D.S., 1981: La arquitectura griega y romana, Madrid.

SCHUBART, H., 1967: Frühe Randkulturen des Mittelmeerraumes. Korsika-Sardinien-Balearen-lberische Halbinsel, 1957, 178-180, Baden-Baden.

SHEFTON, B.B., 1982: "Greek and Greek import in South of the Iberian Peninsula. The archaeological evidence", en H.G. Niemeyer (ed.): Phönizier im Western, 347-348, figs. 2-3, Maguncia.

SPRENGER, M. y BARTOLONI, G. 1983: Etruschi. L'arte, Milán.

STA. CROIX, 1988: La lucha de clases en el Mundo Griego Antiguo, 333, Barcelona.

STEINGRÄBER, ST., 1985: Catalogo ragionato della pittura etrusca, Milán.

TORELLI, M. (coord.), 2001: Gli Etruschi, Monza.

ZEVI, F., 1990: Paestum, Nápoles. 